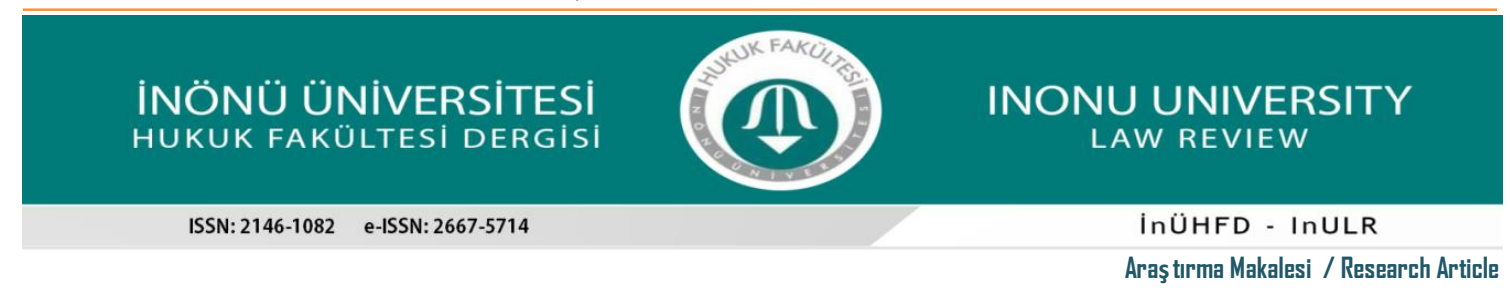

\title{
2863 SAYILI KÜLTÜR VE TABİAT VARLIKLARINI KORUMA KANUNU M.65 SUÇLARININ KANUNILLIK İLKESİ BAKIMINDAN DEĞERLENDIRMESİ
}

\author{
EVALUATION OF THE CRIMES STIPULATED UNDER ARTICLE 65 OF THE LAW NUMBERED \\ 2863 ON CONSERVATION OF CULTURAL AND NATURAL ASSETS IN RELATION TO THE \\ PRINCIPLE OF LEGALITY
}

Makale Bilgi

Gönderi: 28/10/2021

Kabul : 09/02/2022

\section{Anahtar Kelimeler}

Doğal Sit,

Sürdürülebilir Koruma ve Kontrollü Kullanım Alani,

Kanunîlik İlkesi.

\section{Article Info}

Received: $28 / 10 / 2021$ Accepted: 09/02/2022

\section{Keywords}

Natural Site,

Sustainable

Conservation and

Controlled Areas of

Usage,

The Principle of Legality.

\author{
Gülsün AYHAN AYGÖRMEZ $\stackrel{\text { M }}{\text { (iD }}$
}

\begin{abstract}
10.21492/inuhfd.III6044 do
Özet

Özel Kanunlar içerisinde 2863 sayılı Kültür ve Tabiat Varlıklarını Koruma Kanunu m.65
içerisinde yer alan suçlar kanunîlik ilkesi bakımından özellikle mercek altına alınması gereken suçlardandır. Zira ilgili normlarda geçen maddî unsurların tanımlarına 2863 sayılı Kanun içerisinde yer verilmediği gibi, maddî unsurlara esas teşkil edecek hususlar sıklıkla idarî düzenlemeler yoluyla öngörülmüş, değiştirilmiş ve genişletilmiştir. Söz konusu genişlemeye ise bizzat Kanun'un kendisi dahi uyum sağlayamamıştır. Yapılan değişikliklerin başında, sürdürülebilir koruma ve kontrollü kullanım alanlarına ilişkin hükümler gelmektedir. Sürdürülebilir koruma ve kontrollü kullanım alanı kavramına 2863 sayılı Kanun kapsamında değinilmemiş, bunların Kanun'da tanımlanmış doğal sit kavramının bir türü olduğu Yönetmelik ile öngörülmüş; buna ek olarak bu alanlarda yapılmasına izin verilen faaliyetlerle, izne tabi olmayan faaliyetlerin nelerden ibaret olduğu Bakanlık ilke kararlarına bırakılmıştır. Suçların maddî ve manevî unsurunun oluşumuna esas teşkil edecek tüm bu kurucu hususların idarî düzenlemelere bırakılması, ceza hukukunda kıyas yasağı başta olmak üzere, kanunsuz suç ve ceza olmaz ilkesini bünyesinde barındıran kanunîlik ilkesi bakımından ciddi soru işaretleri yaratmaktadır.
\end{abstract}

\begin{abstract}
The crimes included in Art. 65 of the Law on Conservation of Cultural and Natural Assets No. 2863, which is one of the Special Laws, are among the crimes that should be particularly examined in terms of the principle of legality. Because the definitions of the material elements of crimes are not included in the Law No. 2863, the matters that will form the basis of the material elements are often stipulated, changed and expanded through administrative regulations. Even the Law itself could not adapt to this enlargement. Provisions on sustainable conservation and controlled areas of usage are at the forefront of the changes made. The concept of sustainable protection and controlled areas of usage was not mentioned within the scope of Law No. 2863; it was stipulated in the Regulation that these are a type of natural site concept defined in the Law. In addition, the activities that are allowed to be carried out in these areas and the activities that are not subject to permission are left to the Ministry's policy decisions. Subjecting all these founding issues, which will constitute the basis for the formation of the material and moral elements of the crimes, to administrative regulations raises serious questions in terms of the principle of legality, which includes the principle of no crime and punishment without law, especially the prohibition of analogy in criminal law.
\end{abstract}

* Doç. Dr., İstanbul Gedik Üniversitesi, Hukuk Fakültesi, Ceza ve Ceza Muhakemesi Hukuku Anabilim Dall. Atıf Şekli | Cite As: AYGÖRMEZ AYHAN Gülsün, "2863 Sayılı Kültür ve Tabiat Varlıklarını Koruma Kanunu m.65 Suçlarının Kanunilik İlkesi Bakımından Değerlendirilmesi”, İnÜHFD, 13(1), 2022, s.94-109. İntihal | Plagiarism: Bu çalışma intihal programında kontrol edilmiş ve en az iki hakem incelemesinden geçmiştir. | This article has been controlled via a plagiarism software and reviewed by at least two blind referees 


\section{EXTENDED SUMMARY}

In article 65 of the Law on the Conservation of Cultural and Natural Property (LCCNP), 4 crimes are foreseen. Two of them are included in the first paragraph: "Despite being notified or announced in accordance with this Law, those who intentionally caused the registered site areas and, immovable cultural and natural assets that are required to be protected and, protected areas to be demolished, deteriorated, ruined, destroyed or damaged in any way whatsoever, shall be sentenced to imprisonment from two years to five years and a judicial fine up to five thousand days." According to the second paragraph, "Those who give demolition or construction permits in violation of this Law shall be sentenced to imprisonment from two to five years and a judicial fine up to five thousand days." In the third paragraph, a aggravated form of the crime is included through the provision stipulating that if the acts specified in the first and second paragraphs are committed with the aim of smuggling the cultural and natural assets that are required to be protected, abroad the penalties to be imposed are increased by one fold. According to the fourth paragraph, Those who make or have done the renovations and repairs, which are not subject to the license within the scope of Article 21 of the Construction Law No. 3194 in the immovable cultural and natural assets and their conservation areas and protected areas, without obtaining permission, or in violation of the permission, from the authorized administrations in places where protection, implementation and inspection offices have been established within them with regard to the cultural assets; from the regional board directorate of protection in places where protection, implementation and inspection offices have not been established; and from the provincial directorate of environment and urbanism with regard to the natural assets and natural site areas, shall be sentenced to imprisonment from six months to three years or a judicial fine.

The realization of the aforementioned crimes depends on the fact that the place subject to the acts of the crime is within the scope of the Law on the Conservation of Cultural and Natural Property. For this, the aforementioned place must be notified or announced as a site area, immovable cultural and natural assets to be protected or a protected area. Definitions of these places that may be registered, made in LCCNP Art. $1 \mathrm{I}$ a, but the definition of sustainable conservation and controlled usage area is not included here. Afterwards, with Article Art. 6/2 of the Regulation on the Procedures and Principles Regarding the Determination, Registration and Approval of the Protected Areas (Regulation) "natural site areas are divided into three categories as "sensitive areas to be strictly protected, qualified natural protection areas and sustainable protection and controlled usage areas". Thus, the concept of natural sites has been expanded by including the concept of sustainable conservation and controlled usage area. In the Regulation, a generally accepted definition of this area was not made; instead, the distinctive features of these areas were listed (article 9 of the Regulation). In the following process, these distinctive features have undergone changes and transformations through both the Regulation and the Ministry's policy decisions.

The fact that definitions and content in question include all the material elements of the crime - especially the element of damage, construction and physical intervention or maintenance and repair, etc. shall be taken into account during interpretation and that it will play a fundamental role is an issue that should not be overlooked. In addition to all these, it is also clear that the LCCNP itself could not keep up with the enlargement made by the Regulation. For example, the provision of Article 9 on "unauthorized intervention and prohibition of use" that will be based on the systematic interpretation of the crimes within the scope of Art. 65 of the LCCNP is far from covering the areas of sustainable conservation and controlled use. Besides, it is not clearly stipulated in the LCCNP that which activity is subject to permission and which is not in terms of the crime of construction and physical intervention without obtaining permission. On the contrary, this issue is left to the regulations or policy decisions. The aforementioned administrative regulatory processes have changed frequently over time and have moved away from being predictable and traceable for the average human population that makes up the society. Permission is a founding element that constitutes the basis of the criminal charge and sanction both under paragraph 1 and paragraph 4 of Art. 65 of the LCCNP, and therefore, leaving the basis of this element to administrative regulatory proceedings instead of the LCCNP should be examined in terms of the principle of legality.

All these mentioned issues require the evaluation of the relevant norm in terms of the prohibition of analogy and the principle of legality (Constitution Art. 38; TPC Art. 2). In short, the principle of legality, which means being legal, is defined in Art. $38 \mathrm{I}$, III of the 1982 Constitution and Art. 2 of the TPC is one of the main principles that guarantee fundamental rights in criminal law. Pursuant to Article 38 of the Constitution, "No one can be punished for an act that was not considered a crime by the law in force at the time it was committed". Pursuant to Art. 2 of the TPC, "No one can be penalized and a security measure cannot be applied for an act that is not expressly considered a crime by law. No penalty or security measure other than the penalties and security measures written in the law can be imposed. No crime or punishment can be imposed with the regulatory processes of the administration. Analogy cannot be made in the implementation of the provisions of the laws that include crime and punishment. The provisions containing crime and punishment cannot be interpreted broadly in a way that leads to analogy. In addition according to, paragraph 10 of Art. 61 of the TPC "Penalties cannot be increased, decreased, or changed unless expressly written in the Law.". In addition to all these, it is absolutely imperative that the scope of the material element of the crime is in a predictable clarity for the average human population in a society and that everyone can follow it. In this context, in this paper, firstly, explanations about the principle of legality will be given. After that, the current situation regarding the crimes in question will be determined based on the sustainable protection and controlled usage area. After that, the compatibility of these regulations with the principle of legality and its sub-elements (principle of certainty, prohibition of analogy, prohibition of retroactivity) will be tried to be revealed. 


\section{GİRIŞ}

Kültür ve Tabiat Varlıklarını Koruma Kanunu (KültürTK) m.65 içerisinde 4 adet suç öngörülmektedir. Bunlardan ikisi birinci fikrada yer almaktadır:

"Tescil edilen sit alanları ve korunması gerekli taşınmaz kültür ve tabiat varlıkları ile korunma alanlarının bu Kanuna göre tebliğ veya ilan edilmiş olmasına rağmen yıkılmasına, bozulmasına, tahribine, yok olmasina veya her ne suretle olursa olsun zarar görmesine kasten sebebiyet verenler ile izin alınmaksızın inşaî ve fizikî müdahale yapanlar veya yaptıranlar, iki yıldan beş yıla kadar hapis ve beş bin güne kadar adli para cezasıyla cezalandırılır."

İkinci fikraya göre "Bu Kanuna aykırı olarak yıkma veya imar izni verenler, iki yıldan beş yıla kadar hapis ve beş bin güne kadar adli para cezasıyla cezalandırılır." Üçüncü fikrada ise "birinci ve ikinci fikralarda belirtilen fiiller, korunması gerekli kültür ve tabiat varlığını yurt dışına kaçırmak amacıyla işlenmiş ise verilecek cezalar bir kat artırılır" hükmü ile bir nitelikli hâle yer verilmiştir. Dördüncü fikraya göre ise:

"Taşınmaz kültür ve tabiat varlıkları ile bunların koruma alanları ve sit alanlarında, 3194 sayılı İmar Kanunu'nun 21. maddesi kapsamına giren ruhsata tabi olmayan tadilat ve tamiratları, kültür varlıkları yönünden bünyesinde koruma, uygulama ve denetim büroları kurulmuş yerlerde yetkili idarelerden, koruma, uygulama ve denetim büroları kurulmamış yerlerde koruma bölge kurulu müdürlüklerinden; tabiat varlıkları ve doğal sit alanları yönünden ise çevre ve şehircilik il müdürlüklerinden izin almaksızın ya da izne aykırı olarak yapanlar veya yaptıranlar, altı aydan üç yıla kadar hapis veya adli para cezası ile cezalandırılır."

Anılan suçların gerçekleşebilmesi, suç fiillerine konu yerin Kültür ve Tabiat Varlıklarını Koruma Kanunu kapsamında olmasına bağlıdır. Bunun için söz konusu yerin, sit alanı, korunması gerekli taşınmaz kültür ve tabiat varlıkları ya da korunma alanı olarak tescilinin, tebliğ veya ilan edilmiş olması gerekmektedir. Tescili söz konusu olabilecek bu yerlerin tanımları KültürTK m.1/I a'da yapılmış, ancak burada sürdürülebilir koruma ve kontrollü kullanım alanı tanımına yer verilmemiştir. Sonradan Korunan Alanların Tespit, Tescil ve Onayına İlişkin Usul ve Esaslara Dair Yönetmelik m.6/2 (Yönetmelik) ile "doğal sit alanları; kesin korunacak hassas alanlar, nitelikli doğal koruma alanları ve sürdürülebilir koruma ve kontrollü kullanım alanları olarak üç kategoriye" ayrılmış; böylelikle doğal sit kavramı içerisine sürdürülebilir koruma ve kontrollü kullanım alanı kavramı dâhil edilerek genişletilmiştir. Yönetmelik içerisinde ise bu alanın genel geçer bir tanımı yapılmamış, bunun yerine bu alanların ayırt edici özellikleri sıralanmıştır (Yönetmelik m.9). İlerleyen süreçte gerek Yönetmelik gerekse Bakanlık ilke kararları yoluyla söz konusu ayırt edici özellikler değişim ve dönüşüm geçirmiştir.

Söz konusu tanımlamaların ve içeriğin, suçun tüm maddî unsurlarını - özellikle zarar unsuru, inşaî ve fizikî müdahale ya da bakım onarım vs. - yorumlarken göz önünde bulundurulacağı, esaslı bir rol oynayacağı gözden kaçırılmaması gereken bir husustur. Tüm bunların yanında Yönetmelik eliyle yapılan genişletmeye KültürTK'nun kendisinin ayak uyduramadığı da sabittir. Örneğin KültürTK m.65 kapsamındaki suçların sistematik yorumunda esas alınacak, "İzinsiz müdahale ve kullanma yasağı" ile ilgili m.9 hükmü sürdürülebilir koruma ve kontrollü kullanım alanlarını kapsar olmaktan uzaktır. Bunların yanında izin almaksızın inşaî ve fizikî müdahale suçu bakımından hangi faaliyetin izne tabi olduğu hangisinin olmadığı KültürTK içerisinde açıkça öngörülmemiş, bu husus tam tersine Yönetmelik ya da ilke kararlarına bırakılmıştır. Anılan idarî düzenleyici işlemler ise zaman içerisinde sıklıkla değişikliğe uğramış, toplumu oluşturan ortalama insan kesimi açısından öngörülebilir ve takip edilebilir olmaktan uzaklaşmıştır. İzin, gerek KültürTK m.65/1. fikra gerekse 4. fikra kapsamında suç isnadı ve yaptırımının esasını oluşturan kurucu bir unsurdur ve bu nedenle bu unsurun esasının KültürTK yerine idarî düzenleyici işlemlere bırakılması kanunîlik ilkesi açısından irdelenmelidir.

Aktarılan tüm bu hususlar ilgili normun kıyas yasağı ve kanunîlik ilkesi (Anayasa m.38; TCK m.2) bakımından değerlendirilmesini gerektirmektedir. Kısaca yasal olma anlamına gelen kanunîlik ilkesi, 1982 Anayasası m.38/I, III ve TCK m.2'de öngörülmüş, ceza hukukunda temel hakları güvence altına alan ala ilkelerden biridir. Anayasa'nın 38. maddesi gereği "Kimse, işlendiği zaman yürürlükte bulunan kanunun suç saymadığı bir fiilden dolayı cezalandırılamaz”. TCK m.2 gereği

"Kanunun açıkça suç saymadığı bir fiil için kimseye ceza verilemez ve güvenlik tedbiri uygulanamaz. Kanunda yazılı cezalardan ve güvenlik tedbirlerinden başka bir ceza ve güvenlik tedbirine hükmolunamaz. İdarenin düzenleyici işlemleriyle suç ve ceza konulamaz. Kanunların suç ve ceza içeren hükümlerinin uygulanmasında kıyas yapılamaz. Suç ve ceza içeren hükümler, kıyasa yol açacak biçimde geniş yorumlanamaz".

Ayrıca TCK m.62 gereği “(10) Kanunda açıkça yazılmış olmadıkça cezalar ne artırılabilir, ne eksiltilebilir, ne de değiştirilebilir”. Tüm bunların yanında suça konu bir maddî unsurun, 
kapsamının toplumu oluşturan ortalama insan kesimi açısından öngörülebilir açıklıkta ve herkesçe takip edilebilir nitelikte olması mutlak surette zorunludur. Bu bağlamda mevcut eserde öncelikle kanunîlik ilkesi ile açıklamalara yer verilecektir. Bunun ardından sürdürülebilir koruma ve kontrollü kullanım alanı merkezli olarak söz konusu suçlarla ilgili mevcut durum tespitinde bulunulacaktır. Bunun ardından söz konusu düzenlemelerin kanunîlik ilkesi ve bu ilkenin alt unsurları ile (belirlilik ilkesi, kıyas yasağı, geriye yürüme yasağı) bağdaşırlığı ortaya konulmaya çalışılacaktır.

\section{KANUNÎLİK İLKESİ (NULLUM CRIMEN, NULLA POENA SİNE LEGE)}

Çağdaş ceza hukuku, anayasa hukukunun doğrudan etkisi altında, anayasa hukukunun ilkelerini de istisnasız bir şekilde gözetmek zorunda olan bir hukuk dalıdır. Bu, hukuk devleti olmanın da bir gereğidir. Hukuk devleti, hukukun üstün olduğu, kuvvetler ayrılığı ilkesine ve insan haklarına saygilı bir devlet olup, evrensel bir ilke olan hukuk devleti ilkesi üzerine oturur. Hukuk devleti ilkesi, özgürlüklerin güvence altına alındığı, hukukî güvenin ve korumanın sağlandığı bir devlet yapısını hedefler. Anayasa Mahkemesine göre

"Ceza Hukukunun toplumun kültür ve uygarlık düzeyi, sosyal ve ekonomik yaşantısıyla yakından ilgili olması nedeniyle suç ve suçlulukla mücadele amacıyla ceza ve ceza muhakemesi alanında sistem tercihinde bulunulması Devletin ceza siyaseti ile ilgilidir. Bu bağlamda ceza hukukunda ilişkin düzenlemeler bakımından kanun koyucu Anayasa'nın temel ilkelerine bağlı kalmak koşuluyla, soruşturma ve yargılamaya ilişkin olarak hangi yöntemlerin uygulanacağı, toplumda belli eylemlerin suç sayılıp sayılmaması, suç sayıldıkları takdirde hangi çeşit ve ölçülerdeki ceza yaptırımlarıyla karşılanmaları gerektiği, ... ceza siyaseti araçlarının hangi suçlara nasıl uygulanacağı gibi konularda takdir yetkisine sahiptir." 12

Gerçekten de ceza hukuku norma aykırılığa para cezasından, özgürlüğü bağlayıcı cezalara kadar varan geniş bir yelpazede ağır yaptırımlar uygulayarak, insan hak ve özgürlüklerine ağır bir saldırıda bulunmaktadır. İşte hukuk devleti ilkesi, hukukî koruma ve güvence işlevini ceza hukukunda kanunîlik ilkesi aracılığıyla sağlayacaktır. Bu nedenle kanunîlik (yasallık) ilkesinin, hukuk devleti ilkesinin ceza hukukundaki izdüşümü olduğunu ifade etmek yanlış olmayacaktır.

Yasal olma anlamına gelen kanunîlik ilkesi, 1982 Anayasası m.38/I, III ve TCK m.2'de öngörülmüştür. " "Kimse, işlendiği zaman yürürlükte bulunan kanunun suç saymadığı bir fiilden dolayı cezalandırılamaz" hükmü öngören Anayasa'nın 38. maddesi yanında TCK m.2/I "Kanunun açıkça suç saymadığı bir fiil için kimseye ceza verilemez ve güvenlik tedbiri uygulanamaz. Kanunda yazılı cezalardan ve güvenlik tedbirlerinden başka bir ceza ve güvenlik tedbirine hükmolunamaz."; TCK m.2/II "İdarenin düzenleyici işlemleriyle suç ve ceza konulamaz."; TCK m.2/III "Kanunların suç ve ceza içeren hükümlerinin uygulanmasında kıyas yapılamaz. Suç ve ceza içeren hükümler, kıyasa yol açacak biçimde geniş yorumlanamaz."; TCK m.62 "(10) Kanunda açıkça yazılmış, olmadıkça cezalar ne artırılabilir, ne eksiltilebilir, ne de değiştirilebilir." emri getirmektedir.

Anayasa Mahkemesine ${ }^{4}$ göre suçun ve cezanın kanunîliğini norma bağlayan Anayasa'nın 38. maddesinde düzenlenen suçta ve cezada kanunîlik ilkesi Anayasa'nın 13. maddesinde ifade edilen temel hak ve özgürlüklerin ancak kanunla sınırlanabileceğine ilişkin kuralın suç ve cezalar yönünden özel düzenlemesi niteliğindedir.

"Anayasa'nın anılan maddesinde yer alan suçta ve cezada kanunîlik ilkesi uyarınca hangi fiillerin yasaklandığının ve bu yasak fiillere verilecek cezaların hiçbir kuşkuya yer bırakmayacak biçimde kanunda gösterilmesi, kuralın açık, anlaşılır ve sınırlarının belli olması gerekmektedir. Kişilerin yasak fiilleri önceden bilmeleri düşüncesine dayanan bu ilkeyle temel hak ve özgürlüklerin güvence altına alınması amaçlanmaktadır. Bu kapsamda suç ihdas eden düzenlemelerin belirliliklerinin tespitinde anılan ilkelerin göz önünde tutulması zorunludur." ${ }^{5}$

Anayasa Mahkemesi suçta ve cezada kanunîlik ilkesi uyarınca hangi fiillerin yasaklandiğının ve bu yasak fiillere verilecek cezaların hiçbir kuşkuya yer bırakmayacak biçimde kanunda gösterilmesi, kuralın açık, anlaşılır ve sinırlarının belli olması gerektiğine, kişsilerin yasak fiilleri

\footnotetext{
${ }^{1}$ AYM, E 2015/52, K 2016/1, T 13.1.2016, § 16.

${ }^{2}$ AYM, E 2014/3, K 2014/95, T 22.5.2014.

${ }^{3}$ Kanunîlik ilkesinin tarihsel ve Türk Hukukundaki gelişimi hakkında bkz. BAYTAZ, Abdullah Batuhan: Kanunîlik İlkesi Bağlamında Ceza ve Ceza Muhakemesi Hukukunda Yorum, Onikilevha yayıncılık, İstanbul, 2018, s.19 vd.; ayrıca AYGÜN EŞITTLİ, Ezgi: Suçların ve Cezaların Kanunîliği İlkesi, TBBD, (104), 2013, s.226 vd.; MAHMUTOĞLU, Fatih Selami/KARADENIZ, Serra: Türk Ceza Kanunu Genel Hükümler Şerhi, 2. baskı, Beta yayınevi, İstanbul, 2021, s.6 vd.; Yargıtay kararları ile birlikte GÖKCAN, Hasan Tahsin/ARTUÇ, Mustafa: Yorumlu - Uygulamalı Türk Ceza Kanunu Şerhi, 1. Cilt, m.1-44, Adalet Yayınevi, Ankara 2021, s.7 vd.

${ }^{4}$ AYM, E 2019/9, K 2019/27, T 11/4/2019, § 15; AYM, E 2020/82, K 2021/20, T 18/3/2021, § 13.

${ }^{5}$ AYM, E 2020/82, K 2021/20, T 18/3/2021, § 13.
} 
önceden bilmeleri düşüncesine dayanan ve belirlilik ilkesini kapsayan bu ilkeyle temel hak ve özgürlüklerin güvence altına alınması amaçlandiğına özellikle vurgu yapmaktadır. ${ }^{6}$

Yüksek Mahkemeye ${ }^{7}$ göre kişilerin suç sayılan eylemleri önceden bilmeleri gerektiği düşüncesine dayanan kanunîlik ilkesi, hukuk devletinin esas aldığı değerlerden olup aynı zamanda temel hak ve özgürlükleri en geniş biçimiyle gerçekleştirip güvence altına almakta, bu nedenle de uluslararası hukukta ve insan hakları belgelerinde de özel bir yere ve öneme sahip bulunmaktadır:

"Ceza yaptırımına bağlanan fiilin kanunun 'açıkça' suç sayması şartına bağlanması nedeniyle, suç ve cezalara dair düzenlemelerin şekli bakımdan kanun biçiminde çıkarılması yeterli olmayıp, bunların içerik bakımından da belirli amacı gerçekleştirmeye elverişli olmaları gerekir. Bu açıdan kanunun metni, bireylerin hangi somut eylem ve olguya hangi hukuksal yaptırımın veya sonucun bağlandığını belirli bir açıklık ve kesinlikte öngörebilmelerine imkân verecek şekilde düzenlenmelidir. Bu nedenle belirli bir kesinlik içinde kanunda hangi eylemin hangi hukuksal yaptırıma bağlandığının bireyler tarafından bilinmesi ve eylemlerin sonuçlarının öngörülebilmesi gerekir." ${ }^{8}$

Kanunîlik ilkesinin iki önemli fonksiyonu bulunmaktadır. Bunlardan ilki bireyi hâkimin ve iradenin keyfi kararlarına karşı korumaktır. Diğeri ise hangi hareketlerin yasak olup olmadığını önceden belirterek bireye davranışlarını yönlendirme imkânı vermektir. ${ }^{9}$

Kanunîlik ilkesi aynı zamanda kıyas yoluyla yeni bir suç ihdasına ve ceza normlarının genişletilmesine engel oluşturur. ${ }^{10}$ Gerçekten de kanunîlik ilkesi, "Kanunsuz suç ve ceza olmaz" emriyle iç içe geçmiş ve onunla bütünleşmiştir. ${ }^{11}$ Kanunsuz suç ve ceza olmaz emri çok genel bir tabirle yasa varsa, suç da vardır, ceza da; yasa yoksa ne suç vardır ne de ceza anlamına gelmektedir. $\mathrm{Bu}$ bağlamda kanunîlik ilkesi öncelikle, suç ve ceza normunun yalnızca bir kanun eliyle düzenlenebileceğini (TCK m.2/II), normlar hiyerarşisinde yasa dışında bir hukukî düzenleme ile cezaî norm (suç ya da ceza babında) yaratılamayacağını ifade eder. ${ }^{12}$ Bunun yanında içerisinde ayrıca birçok alt emir ve yasak barındırmaktadır. Bunlar gelenek hukuku yasağı, geriye yürütme yasağı, kıyas yasağı ve belirlilik emri ile idarenin düzenleyici işlemleriyle suç ve ceza konulması yasağıdır. ${ }^{13}$

Örf ve adet, yani gelenek hukukunun ceza hukukunda suç ve ceza yaratması ya da mevcut cezayı artırması (nullum crimen sine lege scripta) (TCK m.2/I) yasaktır. Buna göre birey sadece fiil işlediği zaman Kanunlarda açıkça suç olarak sayılmış bir fiilden ötürü cezalandırılabilir. İşlendiği sırada herhangi bir ceza kanununda bir suç olarak öngörülmemiş bir fiilin, gelenek hukukunda olduğu için cezaî yaptırıma tabii tutulması mümkün değildir. ${ }^{14}$

Ceza hukukunda suçlu zararına kıyas (nullum crimen sine lege stricta) (TCK m.2/III) yasaktır. Kanunun açıkça koyduğu bir cezaya bağlı kalmak zorunluluktur ve kanunda belirlenen cezadan daha ağır bir cezaya hükmetmek, yasayla belirlenmiş ceza sınırının sonradan takdiren

${ }^{6}$ AYM, E 2018/151, K 2019/36, T 15/5/2019, § 17; AYM, E 2015/32, K 2015/102, T 12.11.2015, § 7; AYM, E 2015/52, K 2016/1, T 13.1.2016, § 15; AYM, E 2014/3, K 2014/95, T 22.5.2014; AYM , E 2012/77, K 2013/66, T 22.5.2013.

7 AYM, E 2015/32, K 2015/102, T 12.11.2015, § 7.

${ }^{8}$ AYM , E 2012/77, K 2013/66, T 22.5.2013.

${ }^{9}$ CENTEL, Nur/ZAFER, Hamide/YENERER ÇAKMUT, Özlem: Türk Ceza Hukukuna Giriş, 11. Baskı, Beta Basım, İstanbul 2020, s.46 ; ÖZTÜRK, Bahri/ERDEM, Mustafa Ruhan: Ceza Hukuku ve Güvenlik Tedbirleri Hukuku, 21. Baskı, Seçkin Yayınevi, Ankara, 2021, s., 41; MAHMUTOĞLU/KARADENIZ, s.8; BAYTAZ, s.74.

10 AYM, E 2015/32, K 2015/102, T 12.11.2015, § 7.

${ }^{11}$ Kavramın tarihî geçmişi ve güncel uygulaması konusunda ayrıntılı verilerle BOSTANCI, Gülşah: Avrupa İnsan Hakları Sözleşmesi Bağlamında Türk Ceza Hukukunda Suçta ve Cezada Kanunîlik İlkesi, Yayımlanmamış Yüksek Lisans Tezi, İstanbul Üniversitesi Sosyal Bilimler Enstitüsü, İstanbul 2007, s.15; ayrıca dogmatik esasları bakımından bkz. KANGAL, Zeynel: “Anayasal Güvence Olarak Suçta ve Cezada Kanunîlik İlkesi”, Ceza Hukuku Dergisi, (17) 2011, s.64 vd.; ayrica bkz. CENTEL/ZAFER/YENERER ÇAKMUT, s.46 vd.; ARTUK, Mehmet Emin/GÖKCEN, Ahmet/ALŞAHİN, Mehmet Emin/ÇAKIR, Kerim: Ceza Hukuku Genel Hükümler, 14. Baskı, Adalet Yayınevi, Ankara 2020, s.148 vd.; KOCA, Mahmut/ÜZÜLMEZ, İlhan: Türk Ceza Hukuku Genel Hükümler, 12. Bask1, Seçkin Yayıncılık, Ankara 2019, s.53; ÖZGENÇ, İzzet: Türk Ceza Hukuku Genel Hükümler, 17. Baskı, Seçkin Yayınevi, Ankara, 2021, s.119 vd.; DEMİRBAŞ, Timur: Ceza Hukuku Genel Hükümler, 16. Baskı, Seçkin Yayınevi, Ankara, 2021, s.63; ZAFER, Hamide: Ceza Hukuku Genel Hükümler Ders Kitabı, 7. Baskı, Beta Yayınları, Ankara, 2021, s.57 vd.; ÖZTÜRK/ERDEM, s.40 vd.

12 İdarî düzenleyici işlemlerle suç ve ceza konulamayacağına dair ayrıntılı açıklamalarla KANGAL, s.95 vd.; ayrıca KOCA/ÜZÜLMEZ, s.66 vd.; ayrıca tarihsel süreçle birlikte CENTEL/ZAFER/ÇAKMUT, s.57 vd.; ARTUK/GÖKCEN/ALŞAHIN/ÇAKIR, s.157 vd.

${ }^{13}$ Krş. KORKMAZ, Mehmet: Kanunîlik İlkesinin Bir Sonucu Olarak Ceza Kanunlarının Belirlilik İlkesi, Prof. Dr. Mehmet Emin Artuk'a Armağan, Seçkin Yayınc1lık, 2020, Ankara, s.1448, 1449; BAYTAZ, s.71 vd.; GÖKCAN/ARTUÇ, s.10 vd.; HAKERİ, Hakan: Ceza Hukuku, Genel Hükümler, 18. Baskı, Adalet Yayınevi, Ankara, 2015, s.11 vd.

${ }^{14}$ Krş. BOSTANCI, s.15; KANGAL, s.78 vd.; KOCA/ÜZÜLMEZ, s.60 vd.; CENTEL/ZAFER/ÇAKMUT, s.53 vd. 
arttırmak yasaktır. ${ }^{15}$ Burada yasal yorumla yasak kıyas arasında ince bir çizgi vardır, ${ }^{16}$ ki çizgi hükmü geniş yorumlamakla aşılacaktır (TCK m.2 III son cümle). Geniş yorumlamak, sırf başka bir hüküm/olaya yakın olduğu düşünülerek hükmü amacı dışında, benzeriyle örtüşecek şekilde yorumlamaktır. ${ }^{17}$

Kanunîlik ilkesi ayrıca ceza kanunlarının ve cezaların geçmişteki fiillere etki etmesini (nullum crimen sine lege praevia) (TCK m.2/I) yasaklar. Geçmişe yürüme yasağı TCK'da m.7 içerisinde şu şekilde düzenlenmiştir:

"(1) İşlendiği zaman yürürlükte bulunan kanuna göre suç sayılmayan bir fiilden dolayı kimseye ceza verilemez ve güvenlik tedbiri uygulanamaz. İşlendikten sonra yürürlüğe giren kanuna göre suç sayılmayan bir fiilden dolayı da kimse cezalandırılamaz ve hakkında güvenlik tedbiri uygulanamaz. Böyle bir ceza veya güvenlik tedbiri hükmolunmuşsa infazı ve kanunî neticeleri kendiliğinden kalkar. (2) Suçun işlendiği zaman yürürlükte bulunan kanun ile sonradan yürürlüğe giren kanunların hükümleri farklı ise, failin lehine olan kanun uygulanır ve infaz olunur. (3) Hapis cezasının ertelenmesi, koşullu salıverilme ve tekerrürle ilgili olanlar hariç; infaz rejimine iliş̧in hükümler, derhâl uygulanır. (4) Geçici veya süreli kanunların, yürürlükte bulundukları süre içinde işlenmiş olan suçlar hakkında uygulanmasına devam edilir".

Fiil işlediği anda kanunlarda suç sayılmış bir fiil ise, bundan ötürü yaptırım mümkün iken, fiil işlendikten sonra söz konusu fiilin bir suç olarak düzenlenmesi durumunda, geçmişe gidilerek kişinin söz konusu fiilinden dolayı yaptırım görmesi mümkün değildir. Geçmişte suç olmayan ama o anda suç sayılan fiillerden dolayı kimse cezalandırılamaz. Bir fiilin cezası sonradan arttırılmış dahi olsa, belirleyici olan fiil işlendiği anda mevcut olan cezadır. Bu nedenle sonraki suç gibi sonraki ceza da geçmişe yürümez.

Kanunîlik ilkesi gereği ayrıca idarenin düzenleyici işlemleriyle suç ve ceza normu yaratılması yasaktır. ${ }^{18}$ Kanunîlik ilkesi, suç ve ceza normunun sadece bir kanun olabileceğini emretmektedir. Ceza hukukunun temel haklara en ağır saldırılarda bulunan hukuk dalı olduğu göz önünde bulundurulursa, bu durumun aynı zamanda temel hakların yalnızca yasalar eliyle sinırlandırılabileceği emri öngören Anayasa m.13 gereği olduğu da netlik kazanmaktadır. Kuvvetler ayrıllğı ilkesinin de bir gereği olarak suç ve ceza tertibi sadece yasa koyucuya tanınmış bir yetkidir. ${ }^{19} \mathrm{Bu}$ yetkinin yürütmeye devredilmesi bu nedenle kuvvetler ayrıllı̆̆ ilkesine de aykırı olacaktır. Tüm bunların yanında idari düzenleyici işlemlerin karmaşıklı̆̆ı, takibinin zorluğu, kamuya ilan edilip edilmemesi gibi daha birçok husus belirlilik ilkesinin de ihlaline zemin hazırlayıcı mahiyettedir. Aşağıda aktarılacağı üzere 2863 sayılı Kültür ve Tabiat Varlıklarını Koruma Kanunu'nun 65. ve 9. maddesi tam da bu sebeplerden dolay1 ciddi sorunlar yaratmaktadır.

Bunlara ek olarak kanunîlik ilkesi hukukî güvenceyi belirlilik emriyle sağlamaya çalışır (nullum crimen sine lege certa). ${ }^{20}$ Belirlilik ilkesi, suçu ve cezayı düzenleyen kuralların açık, anlaşılır, belirli olmasını zorunlu kılmaktadır. ${ }^{21}$ Hangi eylemin suç teşkil ettiği tespit edilirken kıyasa varacak derecede geniş yorumlamaya uygun, muğlak, farklı anlamlara gelebilen, ortalama kavrayış yeteneğine sahip kişilerce anlaşılması mümkün olamayacak ifadelere yer verilmemesi gerekmektedir. ${ }^{22} \mathrm{Bu}$ yanıyla belirlilik ilkesinin keyfiliği de önleyici bir işleve sahiptir. ${ }^{23}$

Kanunîlik ilkesi gereğince suç teşkil eden hareketin ve karşıllğı olan yaptırımın kanunda belirtilmelidir; ancak belirlilik ilkesi gereğince kanundaki bu belirleme açık, net ve ortalama bir insan tarafından anlaşılabilir olmalıdır. $\mathrm{Bu}$ yönüyle belirlilik ilkesi, kanunîlik ilkesinin fonksiyonlarını yerine getirebilmesi için oldukça önemli bir ilkedir. ${ }^{24}$

\footnotetext{
${ }^{15}$ Krş. BOSTANCI, s.15; KANGAL, s.85, 86; KOCA/ÜZÜLMEZ, s.61 vd.

16 Kıyas ile yorum arasındaki farklar hususunda bkz. MAHMUTOĞLU/KARADENİ, $\quad$ s.11 vd.; ARTUK/GÖKCEN/ALŞAHIN/ÇAKIR, s.194, $195 \mathrm{vd}$.

${ }_{17}$ Yorum hakkında ayrıntılı bkz. BAYTAZ, s.166 vd., kıyas yasağı hakkında s.319 vd.; yorum metodları hakkında ayrıca SOYASLAN, Doğan: Ceza Hukuku, Genel Hükümler, Yetkin Yayınları, Ankara, 1998, s.94.

${ }^{18}$ Ayrıntılar için bkz. BAYTAZ, s.97; ayrıca bkz. YARSUVAT, Duygun: Yürütme Organının Koyduğu Kaidelerle Suç İhdas1 ve 1961 Anayasas1, Journal of Istanbul University Law Faculty 29(3), 2011, s.540 vd.; KHK'lar eliyle de suç ve ceza ihdas edilemeyeceği yönünde ayrıntılı bkz. GÖKCAN/ARTUÇ, s.20 vd.; ayrıca AYGÜN EŞİTLİ, s.235.

${ }^{19}$ Yasama yetkisinin devredilemezliğine işaret ederek CAN, Osman: Belirlilik İlkesine Anayasal Bakış, AÜEHFD, IX(1-2), 2005, s.105 vd.

${ }^{20}$ Belirlilik ilkesinin tarihsel gelişimi anayasal sorunlar hakkında bkz. CAN, s.89 vd.

21 Krş. BOSTANCI, s.15; ayrıntılı açıklamalarla bkz. KANGAL, s.71 vd.; KOCA/ÜZÜLMEZ, s.57 vd.; CENTEL/ZAFER/ÇAKMUT, s.56 vd.; ayrıntılı açıklamalarla KORKMAZ, s.1449 vd.

${ }^{22}$ KORKMAZ, s.1449.

${ }^{23}$ Ayrıntılı bkz. KORKMAZ, s.1450 vd.; krş ayrıca CAN, s.90.

${ }^{24}$ ARTUK/GÖKCEN/ALŞAHIN/ÇAKIR, s.153; ÖZGENÇ, s.130.
} 
Belirlilik ilkesine göre bireye, bireysel özgürlüklerinin sınırlarını önceden kestirerek, davranışlarının anlamı ve bunların hukuk âlemindeki sonuçlarını öngörebilme olanağı verilmelidir. ${ }^{25} \mathrm{Bu}$ bağlamda ilke norma uyan ya da uymayan davranışların nelerden ibâret olduğunun öngörülebilecek şekilde ifade edilmesi gerektiğini buyurarak, bir nevi birey özgürlüklerinin sınırlarını da çizmiş olmaktadır. Bu bağlamda öncelikle suçun maddî unsurlarının nelerden ibaret olduğunun, herkesçe anlaşılır șekilde değerlendirilebilmesi gerekmektedir. Algılanıp, hukukî değerlendirme sürecinden geçilemeyen, dolayısı ile de muhakeme edilemeyen unsurlar, öngörülebilir addedilemeyecektir. Bu yönüyle belirlilik ilkesi, kanun koyucuya büyük bir görev yüklemektedir. ${ }^{26}$ Burada söz konusu olan kanun koyucunun her unsuru kavramsal olarak açıklaması ve her terime açık tanımlamalar getirmesi değildir. ${ }^{27}$ Burada önemli olan kelimelerin genel anlamı ile bilinen yorum kurallarına uyularak elde edilebilecek genel sonuçlardır. ${ }^{28}$ En nihayetinde kavramsal açıklık ve netlik dışında kanun koyucunun metinden farklı anlamlar çıkmasını önlemek adına noktalama işaretlerine dahi büyük titizlikle dikkat etmesi gerekmektedir. ${ }^{29}$

Anayasa Mahkemesine ${ }^{30}$ göre de,

“Anayasa'nın 2. maddesinde, Türkiye Cumhuriyeti bir hukuk devleti olarak nitelendirilmiştir. Hukuk devletinin temel ilkelerinden biri 'belirlilik'tir. Bu ilkeye göre, yasal düzenlemelerin hem kişiler hem de idare yönünden herhangi bir duraksamaya ve kuşkuya yer vermeyecek şekilde açık, net, anlaşılır, uygulanabilir ve nesnel olması, ayrıca kamu otoritelerinin keyfi uygulamalarına imkân tanımaması gerekir. Belirlilik ilkesi, hukuksal güvenlikle bağlantılı olup birey, yasadan belirli bir kesinlik içinde, hangi somut eylem ve olguya hangi hukuksal yaptırımın veya sonucun bağlandığını bilmelidir. Birey ancak bu durumda kendisine düşen yükümlülükleri öngörebilir ve davranışlarını düzenleyebilir. Hukuk güvenliği, normların öngörülebilir olmasını, bireylerin tüm eylem ve işlemlerinde devlete güven duyabilmesini, devletin de yasal düzenlemelerde bu güven duygusunu zedeleyici yöntemlerden kaçınmasını gerekli kılar."

Yargıtay $^{31}$ da aynı şekilde, bireyin devlete güven duyması ve bu bağlamda da hukukî güvenliğin sağlanmasının normların öngörülebilir olmasına bağlı olduğuna vurgu yapmaktadır.

Belirlilik ilkesi bakımından tartışmalı hususların başında atıf suçları denilen, çerçeve (beyaz) hükümler gelmektedir. 2863 sayılı Kültür ve Tabiat Varlıklarını Koruma Kanunu'nun 65. maddesinin, örtülü 9. madde atfı ve aynı zamanda "izin" koşulu nedeniyle idari işlemlere bağlılık yaratılması, bu hususu ayrıca ele almayı gerektirmektedir.

\section{ATIF SUÇLARI VE KANUNİLIK İLKESI}

Türk ceza hukuku doktrininde ${ }^{32}$ beyaz hüküm ya da açık ceza normu denilen, "atıf suçları" 33 , tipiklik içerisinde sadece cezalandırmaya ilişkin hükümlere yer verilip, yasağın içeriksel olarak doldurulması başka normlara bırakılır. Dolayısıyla bu suçlar başka normlara göndermede bulunan suçlardır. ${ }^{34}$ Atıf tekniği ile ceza hukuku normu, başka bir cezaî norma veya sıklıkla ceza hukuku alanı dışında bir norma, ceza hukukunu da, ilgili hukuk alanına bağlamakta, bağımlı kılmaktadır. Açık, örtülü, içerisinde ve dışa olmak üzere çeşitli türleri bulunan atıf ${ }^{35}$ yoluyla suç yaratma tekniği çeşitli gerekçelerle isabetli ve pratik görülmektedir. ${ }^{36}$ Teknik, ceza hukukunun değişikliklere daha

\footnotetext{
${ }^{25}$ Ayrıntılı BOSTANCI, s.15; ayrıca KANGAL, s.71 vd.; BAYTAZ, s.72 vd.; KORKMAZ, s.1449 vd.

${ }^{26}$ ARTUK/GÖKCEN/ALŞAHIN/ÇAKIR, s.165; ÖZTÜRK/ERDEM, s.45

${ }^{27} \mathrm{Krş.} \mathrm{BAYTAZ,} \mathrm{s.76.}$

${ }^{28} \mathrm{Krş.} \mathrm{örneklerle} \mathrm{BAYTAZ,} \mathrm{s.76} \mathrm{vd.}$

${ }^{29}$ GÖKCAN/ARTUÇ, s.13.

30 AYM, E 2014/122, K 2015/123, T 30.12.2015; AYM, E 2011/18, K 2012/53, T 11.4.2012; Alman Anayasa Mahkemesinin belirlilik ilkesi kriterleri bakımından bkz. CAN, s.101 vd.

${ }^{31}$ CGK, E 2019/8-249, K 2019/499, T 25.06.2019.

${ }^{32}$ Bkz. KOCA/ÜZÜLMEZ, s.58; CENTEL/ZAFER/ÇAKMUT, s.57; ayrıntılı açıklamalar için bkz. KORKMAZ, s.1459 vd.; ayrıca bkz. MAHMUTOĞLU/KARADENIZ, s.17; çerçeve yasalarla bağımız suç oluşturma hakkında CAN, s.113 vd.

${ }^{33}$ Atıf türleri kullanılarak oluşturulan atıf suçları hakkında ayıntılı açıklamalar için bkz. AYGÖRMEZ, Gülsün Ayhan: Çevre Ceza Hukuku, Çevre Ceza Genel Hükümler, Cilt 1, 1. Bask1, On İki Levha Yayıncılık, İstanbul 2021, s.35 vd.;

${ }^{34}$ Ayrıntılı açıklamalar için bkz. AYGÖRMEZ, s.35, 37 vd.

${ }^{35}$ Bkz. AYGÖRMEZ, s.37 vd.

${ }^{36}$ Ayrıntılı veri ve Alman kaynaklarıyla bkz. AYGÖRMEZ, s.40; Alman Federal Anayasa Mahkemesi de (BVerfG, NJW 1987, 3175 vd.) anayasaya aykırılık tespit edemediği tekniği 3 gerekçe ile zarurî görmektedir: Bunların başında, hukuk düzeni ya da hukuk alanları arasında bütünlük ilkesi gelmektedir. Ceza hukuku, idare hukukuna göre uygun olan ya da izin verilmiş olan bir fiili cezalandıramaz. İkinci temel etken, pratikliktir. Bu teknik sayesinde, o zamana kadar geliştirilmiş olan idare hukuku kavramları, kullanılmaya devam edecektir. Üçüncü gerekçe ise, çevre ceza hukukunun dinamikliği ve esnekliğidir. Çevre ceza hukuku böylece, gelişmelere daha iyi uyum sağlayacaktır. Karar için bkz. AYGÖRMEZ, s.40 vd.
} 
kolay uyum sağlamasını ve kanun ekonomisi sağlayarak, diğer hukuk alanlarına giren yasal düzenlemelerin ceza hukukunca yeniden tekrarlanmasını engellemekte, bu da hukuk bilimleri arasında bütünlüğün sağlanmasına dolaylı olarak hizmet etmektedir. Ayrıca tekniğin şu an için bir alternatifi de bulunmamaktadır.

Söz konusu yöntemle ceza hukuku sıklıkla idare hukukuna [ya da hükümlerine] bağımlı hâle gelmekte, bu bağımlılık idare hukuku kavramına veya idarî işlemlere bağımlılık vs. şeklinde olabilmektedir. ${ }^{37}$ İdareye kavramsal bağımlılık, ceza hukukuna yabancı idare hukuku normlarının, ceza hukukunca üstlenilmesi ile meydana gelen bağımlılık türüdür. ${ }^{38} \mathrm{Bu}$ normlar ceza hukukunun kendi normları olmadıklarından, yorumlanmaları da idare hukuku göz önünde bulundurularak gerçekleştirilmektedir. Mesela KültürTK m.65 kapsamındaki inşaî ve fizikî müdahale kavramı böyledir. İdarî işlemlere bağımlılık, çevre ceza hukukunun idarî bir makamın verdiği bir idarî işlem ya da karara bağlı olmasını ifade etmektedir. ${ }^{39}$ Bu bağımlılık türü işlemsel bir bağımlılık olup, KültürTK m.65 kapsamında ilgili "izin" kavramı kullanılmak suretiyle meydana getirilmektedir.

Ceza hukukunun idare hukukuna bir hukuk dalı olarak ya da kavramsal olarak bağımlılığını Alman Anayasa Mahkemesi ${ }^{40}$ bazı şartlar altında belirlilik ilkesine uygun bulunmaktadır. Atıfta bulunulan hükümler aracıllğı ile yeteri kadar belirlilik sağlanabilmesi için aranması gereken unsurların başında ceza hukuku kanun koyucusunun daha da özenli davranarak, neyin cezalandırılabilir neyin cezalandırılamaz olduğunu, cezanın türü ve miktarını yeteri kadar açık bir şekilde ilgili ceza normunda belirtmesi zorunluluğu gelmektedir. ${ }^{41}$ Yükümlülük doğuran idare hukuk mevzuatı hükümlerinin ise, mutlaka yeteri kadar belirli olması gerektiğine özellikle vurgu yapılmakta; ilgili düzenlemelerden hukukî kınamaya neden olacak somut hareketin çıkarılabiliyor olması icâp etmektedir. ${ }^{42}$

Ceza hukukunun sadece idare hukuku mevzuatına değil, ayrıca idarî işlemlere bağımlı hâle getirilmesi de anayasaya aykırı kabul edilmemektedir. ${ }^{43}$ Burada idarenin kararları veya işlemleri ceza hukuku açısından da belirleyici olduğundan, belirlilik ilkesi gereklerine daha da fazla uyulması gerekmektedir. ${ }^{44}$ Belirlilik ilkesi ile beraber önemli diğer bir ilke Alman Anayasası'nın m.104/I cümle I'de öngördüğü yasallık ilkesidir. Yasallık ilkesi gereği kanun koyucu, cezalandırmaya ilişkin koşulları idarî makamlara bırakmadan, bizzat kendisi ve mutlaka bir kanun içerisinde düzenlemek zorundadır. ${ }^{45} \mathrm{Bu}$ bağlamda bir ceza normunun yasa değil de, yönetmelik eliyle somutlaştırılması Alman Anayasa Mahkemesi ${ }^{46}$ tarafından sadece belirli koşullar altında mümkün kabul edilmektedir. Buna göre yönetmelik eliyle somutlaştırma sadece, yönetmeliğin işlevinin, yalnızca kavramın açıklanmasına indirgendiği hâller için meşrû kabul edilebilecektir. Dolayısıyla ceza kanunundaki atıf hükmü cezalandırılacak hareketi genel hatlarıyla betimlemek zorundadır, bu görevi kesinlikle bir yönetmeliğe bırakamaz. Bunun yanında ayrıca ilgili yükümlülük öylece ceza hukukuna alınmamalı, ilgili ceza normunun koruma amac1 mutlaka göz önünde bulundurulmalıdır. ${ }^{47}$ Normun koruma amacı dışındaki hususlar, ceza hukukunun ilgili maddesi bakımından bağlayıcı olamaz.

Aktarılan Alman Anayasa Mahkemesinin belirlilik ilkesi açısından saydığı koşullar şu şekilde özetlenebilir: Atıf yoluyla tipik hareketin belirlilik sağlanacak derecede genel hatlarıyla mevcut ceza yasası içerisinde öngörülmesi zorunludur. Bu husus normlar hiyerarşisinde kanunun altında bir düzenlemeye bırakılmaz. İdare hukuku normları ve özellikle cezalandırmaya esas alınacak yükümlülükler ceza normu kapsamında değerlendirilirken, ilgili ceza normunun koruma amacı göz ardı edilmeyecektir. İlgili normun koruma amacı dışındaki bir yükümlülük istediği kadar idare hukukuna aykırılık teşkil etsin, ceza kanunu kapsamında bir suç olarak değerlendirilemeyecektir. Bu ayrıca ceza hukukunun son çare olması ve müstakilliğinin bir sonucudur.

Ceza hukukunun idareye bağımlılı̆̆ı, ceza hâkiminin idarî kararlara bağl görünüyor olması ya da tersine idarî makamın vereceği kararın dolaylı olarak cezaî bir hüküm oluşturacak olması,

\footnotetext{
${ }^{37}$ Tüm diğer bağımlılık türleri bakımından bkz. AYGÖRMEZ, s.38 vd.

${ }^{38}$ Ayrıntılı AYGÖRMEZ, s.38.

${ }^{39}$ Ayrıntılar için AYGÖRMEZ, s.38.

${ }^{40}$ BVerfG, NJW 1987, s.3175 (3175 vd.).

${ }^{41}$ BVerfG, NJW 1987, s.3175 (3175).

42 Alman kaynaklara atıfta bulunarak AYGÖRMEZ, s.40 vd.

${ }^{43}$ BVerfG, NJW 1987, s.3175 (3175 vd.).

${ }^{44}$ Ayrıntılar için bkz. AYGÖRMEZ, s.40 vd.

${ }^{45}$ Alman kaynaklarla beraber ayrıntılı AYGÖRMEZ, s.40 vd.

${ }^{46}$ BVerfG, NJW 1987, s.3175 (3175 vd.).

${ }^{47} \mathrm{Krş.} \mathrm{AYGÖRMEZ,} \mathrm{s.40} \mathrm{vd.}$
} 
idarenin yargıya ya da yargının idareye karışması anlamında kuvvetler ayrılığı ilkesi açısından da tartışma yaratmaktadır. Bu husus Alman Federal Anayasa Mahkemesi ${ }^{48}$ tarafından ACK m.327 II bent 1 kapsamında ele alınmış ve ilgili maddeler anayasaya uygun kabul edilmiştir. Mahkemeye ${ }^{49}$ göre, her ne kadar ceza mahkemesi idarî kararlara bağlı olsa da, ceza mahkemelerinin idare mahkemesi kararlarına genel olarak bağımlılıkları söz konusu değildir. Her bir hukuk alanının kendine özgü hükümleri ve hedeflerinin olması sebebiyle, ceza mahkemelerinin yorum zorluklarını kendi hukuk alanındaki olanaklarla aşmaları gerekmektedir. Yüksek Mahkeme, ceza mahkemesi idare mahkemesi kararlarından bağımsızdır demekte, dolayısıyla idarî kararlara bağımlılığı, ceza hukukunun kendi norm ve ilkelerine uygunlukla sınırlamaktadır. Karar merci bir ceza yargı makamı ise ortada bağımsız bir yargılama bulunduğundan, idarenin yargıya karışması söz konusu olamaz.

Türk ceza hukuku bakımından konu Anayasa Mahkemesi ${ }^{50}$ tarafindan mülga TCK zamanında özellikle m.526 ile bağlantılı olarak kanunîlik, belirlilik ve kuvvetler ayrılığ 1 ilkesi bakımından tartışılmıştır. ${ }^{51}$ Mülga TCK m.526 I içerisinde, yetkili makamlar tarafından verilen bir emri dinlemeyen ya da bu yolda alınmış bir tedbire uymayanların eylem başka normlara göre suç oluşturmadığ 1 takdirde bu hükme göre cezalandırılacakları öngörülmekte idi. Mülga TCK m.526 I'in kanunîlik ilkesine ve kuvvetler aykırılığı ilkesine aykırılığı iddialarını incelemeye alan Anayasa Mahkemesi ${ }^{52}$ normun hukuk dilme ve kanunlara girmiş ve üstelik bir kısmı Anayasa'da yer almış, anlamının yoruma muhtaç olmadığı ve kişilere göre değişmediğini, bunun yanında suç unsurlarının ve suçun ne gibi eylemleri kapsadığının açıkça belirtildiğine ve cezası da önceden saptandığını, kanunda esaslı hükümleri saptandıktan sonra acil olaylarda kimi makamlara tedbir almak yetkisinin bırakmasının anayasal bir ihlâl olmadığına karar vermiştir.

$\mathrm{Bu}$ bağlamda Anayasa Mahkemesine göre, özellikle suç ve cezada kanunîlik ilkesi bakımından müeyyidenin, dolayısıyla cezanın yasada açıkça yer alması; suç unsurlarının yasa

${ }^{48}$ BVerfG, NJW 1987, s.3175 (3176)

${ }^{49}$ BVerfG, NJW 1987, s.3175 (3176).

${ }^{50}$ AYM, E 1973/12, K 1973/24, T 07.06.1973: “Türk Ceza Kanunu'nun 526. maddesinin birinci fikrasinda yer alan, 'amme emniyeti' (kamu güvenliği) 'amme intizamı' (kamu düzeni) ve 'mülahaza' gibi deyimler ve sözcükler itiraz yoluna başvuran mahkemenin kararında ileri sürüldüğü gibi kesinlik taşımayan, yoruma muhtaç, kişilerin bakış açısına göre değişiklik gösteren sözcüklerden ibaret olmayıp, tersine anlamları uygulamalarla belirmiş, hukuk ve Anayasa diline girmiş kavramlardandır. Örneğin Anayasa'nın değişik 11., 16., değişik 19., 28., değişik 29., ve değişik 46. maddelerinde, 'milli güvenlik', 'kamu düzeni', ve değişik 15. maddesinde 'kanunla yetkili kılınan merci' deyimlerinin kullanıldığı görülmüştür. Hukuk dilme ve kanunlara girmiş ve üstelik bir kısmı Anayasa' da yer almış bu terimlerin anlamının yoruma muhtaç olduğundan ve kişilere göre değişebileceğinden söz edilerek ve bu gibi nedenlere dayanılarak kanun hükmünün Anayasa'ya aykırılığının ileri sürülemeyeceği şüphesiz bulunmaktadır. İptali istenen Türk Ceza Kanunu'nun 526. maddesinin birinci fikrasında suç unsurları da açık olarak belirtilmiştir. Kanunun bu hükmüne göre bir fiilin suç teşkil edebilmesi için yetkili makamlarca verilmiş bir emir veya alınmış bir tedbir olması, bu emir veya tedbirin ya adli muamelelere, ya kamu güvenliğine, ya kamu düzenine yahut da genel sağlığa ilişkin bulunması ve ayrıca bu emir veya tedbirin kanunlara ve tüzüklere de aykırı bulunmaması gerekmektedir. Ancak bu ögeler var olduğu takdirde yetkili makamın emir veya tedbirine aykırı davranış bu hükme göre suç teşkil edecektir. Bu yoldaki emir veya tedbirin önceden neşir ve ilan edilerek halka duyurulmuş olmasının gerektiği de izahtan varestedir. Kanunda 'yetkili makam'dan da söz edildiğine göre kanun veya tüzükle bu türlü meselelerde emir vermek veya tedbir almak yetkisi tanınmamış kişilerin emir ve tedbirlerinin burada söz konusu olamayacağından şüphe edilemez. Türk Ceza Kanunu'nun 526. maddesinin birinci fikrası kuralı ile, adli işlemleri iyi ve salim bir biçimde yürütmek, kamu düzenini, kamu güvenliğini, genel sağlığı korumak, bu alanlarda gerektiğinde daha çabuk ve yerinde tedbirler alınmasını sağlamak ereği güdülmüştür. Görülüyor ki Türk Ceza Kanunu'nun 526. maddesinin söz konusu fikrasında suçun ne olduğu ve cezası açıkça belirtilmiştir. Bu maddeye aykırı hareketten açılan bir kamu davasında yetkili ve görevli mahkemenin; emri veren veya tedbiri alan makamın kanun ve tüzük hükümlerine göre böyle bir emir vermeye veya tedbir almaya yetkili olup olmadığını araştıracağı gibi kanunda yazılı öteki koşul ve öğelerin de bulunup bulunmadığını saptayacağ kararı vereceği tabii olduğundan Nazilli Sulh Ceza Mahkemesinin itiraz kararında ileri sürülen ve yukarıda [...] gösterilen nedenlerden hiçbirini haklı ve yerinde bulmağa olanak yoktur. İtiraz konusu 526. maddenin birinci fikrası kuralının, Anayasa'nın 5. maddesinde ver alan 'Türkiye Büyük Millet Meclisine ait olan yasama yetkisinin devredilemeyeceği' ve yine Anayasa'nın 33. maddesiyle Türk Ceza Kanunu'nun 1. maddesinde açılanan 'kanunsuz suç ve ceza olmaz' ilkelerine aykırı düştüğünün öne sürülmesi de mümkün görülmemektedir. Anayasa Mahkemesi’nin 10/12/1962 günlü 1962/198-11 sayılı kararında (Anayasa Mahkemesi Kararlar Dergisi: Sayı 1. sayfa 29 - 36 ve 24/1/1963 günlü, 11316 sayılı Resmi Gazete) da belirtildiği gibi yasama organının, kanun yaparken bütün olasılıkları göz önünde bulundurarak ayrıntı kuralları da saptamak yetkisi varsa da sık sık değişen durumlar ve ihtiyaçlar karşısında bu organın, yapısı bakımından ağır işlemesi ve günlük olayları izleyerek zamanında gerekli tedbirleri almasının güçlüğü dolayısıyla kanunda esaslı hükümleri saptadıktan sonra acil olaylarda Hükümete veya kimi makamlara tedbir almak yetkisi bırakması da yasama yetkisini kullanmaktan başka bir şey değildir. Bu durum karşısında yasama yetkisinin yürütme organına bırakıldığı gibi bir anlam çıkarmak doğru olamaz. Bundan başka, yukarıda da değinildiği gibi 526. maddenin birinci fıkrasında suçun ne gibi eylemleri kapsadığı açıkça belirtildiğine ve cezası da önceden saptandığına göre itiraz konusu kuralın Anayasa'nın 33. maddesi ile Türk Ceza Kanunu'nun 1. maddesindeki 'kanunsuz suç ve ceza olamaz.' ilkesine de uymayan bir yönü yoktur."

51 Öğreti görüşlerine de yer vererek AYGÖRMEZ, s.43 vd.

52 AYM, E 1973/12, K 1973/24, T 07.06.1973. 
içerisinde açıkça belirtilmiş olması, dolayısıyla neyin suç olduğu-olmadığının yasada açıkça belirtilmesi zorunludur. Kesinlik taşıyan, kişisel bakış açısına göre değişmeyen, anlamları uygulamalarla belirmiş, hukuk ve Anayasa terminolojisi hâline gelmiş dolayısıyla hukuk dilinde oturmuş terimler belirli [belirlilik ilkesine uygun] kabul edilebilecektir. İdarî emir veya tedbirin önceden yayınlanıp ve ilân edilerek halka duyurulmaları belirlilik ilkesinin bir gereğidir [bu da Bakanlık iç düzen Yönergelerinin vatandaş bakımından bağlayıcı olmasını önleyecektir]. Emir vermek veya tedbir almak yetkisinin tanındığ kişilerin, emir ve tedbirlerine uyulması beklenecek, aksi söz konusu olamayacaktır. Tüm bu konularda davaya bakacak mahkemenin emri veren veya tedbiri alan makamın kanun (ve tüzük) hükümlerine göre böyle bir emir vermeye veya tedbir almaya yetkili olup olmadığını araştırma ve kanunda yazılı öteki koşul ve ögelerin de bulunup bulunmadığını saptama ve sonucuna göre gerekli kararı verme konusunda bağımsızlığı söz konusudur (bu son ilkeyle Türk Anayasa Mahkemesi hukuk alanlarının, daha doğrusu ceza hukukunun özerkliğini kabul etmiş olmaktadır).

Yüksek Mahkemenin oldukça kapsamlı bu içtihadından açıkça döndüğü başka bir karara rastlanmamıştır. Ancak bu çalışmanın konusu bakımından özellikle dikkat çekilmesi gereken bir kararı bulunmaktadır. Anayasa Mahkemesi ${ }^{53} 2863$ sayılı Kültür ve Tabiat Varlıklarını Koruma Kanunu'nun 65. maddesinin (a) ve (b) fikralarının Kanun'un 9. maddesi ile birlikte değerlendirilmesi ile idarî organlara suç teşkil eden fiilleri belirleme yetkisi tanındığ 1 ve hukukî belirlilik ilkesinin ihlal edildiği belirtilerek kuralların Anayasa'nın 2. ve 38. maddelerine aykırı olduğunun ileri sürüldüğü bir istemde önemli bir karara imza atarak ilgili normu iptal etmiştir. Kararın merkezindeki sorun, koruma bölge kurulları kararlarının Resmi Gazete' de yayımlanmaması ve herkesin bilgisine sunulmaması nedeniyle ulaşılabilirlik ve öngörülebilirlik açısındandır. $\mathrm{Bu}$ bağlamda Yüksek Mahkeme,

"Hem tescil kararının tebliğ edilmemesi hem de koruma bölge kurulu kararlarının ilgililere duyurulmasını güvence altına alacak bir yasal hükmün bulunmaması karşısında itiraz konusu kurallarda belirtilen cezai yaptırımların bireyler açısından öngörülebilir olmadığı ve suçların kanunîliği ilkesine uymadığı açıktır." sonucuna şu gerekçelerle ulaşmış bulunmaktadır: "2863 sayılı Kanun'un 65. maddesinin (a) fikrasında korunması gerekli taşınmaz kültür ve tabiat varlıklarına zarar verenlerin, (b) fikrasında ise sit alanlarında geçiş dönemi koruma esasları ve kullanma şartlarına, koruma amaçlı imar plânlarına ve koruma bölge kurullarınca belirlenen koruma alanlarında öngörülen şartlara aykırı izinsiz inşaî ve fizikî müdahale yapanların cezalandırılması öngörülmüştür. Buna göre korunması gerekli taşınmaz kültür ve tabiat varlıklarının yıkılmasına, bozulmasına, tahribine, yok olmasına veya her ne suretle olursa olsun zarara uğramalarına kasten sebebiyet verenler ile sit alanlarında geçiş dönemi koruma esasları ve kullanma şartlarına, koruma amaçlı imar plânlarına ve koruma bölge kurullarınca belirlenen koruma alanlarında öngörülen şartlara aykırı izinsiz inşaî ve fizikî müdahale yapanlar veya yaptıranlar cezai yaptırıma tabi tutulmuştur... Anayasa'nın 2. maddesinde yer alan hukuk devletinin temel ilkelerinden birisi 'belirlilik'tir. Bu ilkeye göre, yasal düzenlemelerin hem kişiler hem de idare yönünden herhangi bir duraksamaya ve kuşkuya yer vermeyecek şekilde açık, net, anlaşılır ve uygulanabilir olması, ayrıca kamu otoritelerinin keyfi uygulamalarına karşı koruyucu önlem içermesi gerekir. Belirlilik ilkesi, hukuksal güvenlikle bağlantılı olup birey hangi somut eylem ve olguya hangi hukuksal yaptırımın veya sonucun bağlandığını, bunların idareye hangi müdahale yetkisini doğurduğunu bilmelidir. Birey ancak bu durumda kendisine düşen yükümlülükleri öngörebilir ve davranışlarını belirler. Hukuk güvenliği, normların öngörülebilir olmasını, bireylerin tüm eylem ve işlemlerinde devlete güven duyabilmesini, devletin de yasal düzenlemelerde bu güven duygusunu zedeleyici yöntemlerden kaçınmasını gerekli kılar. Anayasa'nın 38. maddesinin ilk fikrasında, 'Kimse, ... kanunun suç saymadığı bir fiilden dolayı cezalandırılamaz' denilerek 'suçların kanunîliği', üçüncü fıkrasında da 'ceza ve ceza yerine geçen güvenlik tedbirleri ancak kanunla konulur' denilerek, 'cezaların kanunîliği' ilkesi öngörülmüştür. Anayasa'nın 38. maddesine paralel olarak Türk Ceza Kanunu'nun 2. maddesinde yer alan 'suçta ve cezada kanunîlik ilkesi uyarınca, hangi fiillerin yasaklandığı ve bu fiillere verilecek cezaların hiçbir şüpheye yer bırakmayacak biçimde kanunda gösterilmesi, kuralın açık, anlaşılır ve sınırlarının belli olması gerekmektedir. Suçların ve cezaların kanunîliği ilkesi, ceza hukukuna hâkim olan anayasal ilkelerden olup temel hak ve özgürlüklerin önemli güvencelerinden birini oluşturmaktadır. Kişilerin yasaklanmış olan fiilleri önceden bilmeleri ve kendi hareketlerini buna göre ayarlamalarına imkân tanınması düşüncesine dayanan bu ilkeyle ceza sorumluluğu bireylerin bilinçli tercihlerine bağlanmakta ve birey özgürlüğünün güvence altına alınması amaçlanmaktadır. Zira bireylerin hangi fiilin suç oluşturacağını öngörememesi ya da bu konuda çeşitli sürprizlerle karşılaşması, bireyin özgürlüğünü önemli ölçüde kısıtlayacaktır. İtiraz konusu Kanun'un 65. maddesinin (a) ve (b)

${ }^{53}$ AYM, E 2011/18, K 2012/53, T 11.4.2012. 
bentlerinde korunması gerekli taşınmaz kültür ve tabiat varlıklarına zarar verenler ile sit alanlarında geçiş dönemi koruma esasları ve kullanma şartlarına, koruma amaçlı imar plânlarına ve koruma bölge kurullarınca belirlenen koruma alanlarında öngörülen şartlara aykırı izinsiz inşaî ve fizikî müdahale yapanlar veya yaptıranların cezalandırılması öngörülmektedir. Kanun'un tespit ve tescil başlıklı 7. maddesinde korunması gerekli taşınmaz kültür ve tabiat varlıklarının ve doğal sit alanlarının tespitinin Kültür ve Turizm Bakanlığının koordinatörlüğünde yapılacağı ve bu tespitlerin koruma bölge kurulu kararı ile tescil edileceği öngörülmüş̧ür. Ancak bu tespit ve tescilin maliklere tebliği öngörülmemiştir. Maddenin ilk hâlinde maliklere tebliğ de öngörülmüşken 17. 6. 1987 tarih ve 3386 sayılı Kanunla yapılan değişiklikle tebliğ zorunluluğu ortadan kaldırılmıştır. Öte yandan, koruma bölge kurullarınca tespit edilen koruma alanlarında belirlenen şartlara aykırı izinsiz inşâ̂ ve fizikî müdahale yapan ya da yaptıranların cezalandırılması öngörülmektedir. Burada suç teşkil eden fiilin konusunu koruma bölge kurullarınca belirlenen esaslara aykırı izinsiz inşầ ve fizikî müdahaleler oluşturmaktadır. Ancak koruma alanlarında uyulacak şartların neler olduğunu belirleme yetkisi koruma bölge kurullarına tanınmıştır. Herhangi bir sit alanında bulunan korunması gerekli taşınmaza yapılan hangi müdahalelerin suç oluşturacă̆ını belirlemek idarî bir organ olan koruma bölge kurullarına verilmiştir. Kanun'un 57. maddesinin, birinci fikrasının ( $\mathrm{g}$ ) bendinde korunması gerekli taşınmaz kültür ve tabiat varlıkları ve koruma alanları ile sit alanlarına ilişkin uygulamaya yönelik kararlar alma yetkisi bölge kurullarına verilmiştir. Aynı maddenin dördüncü fıkrasının son cümlesinde de bu kararların Kanun ve ilke kararlarındaki dayanakları ile bilimsel gerekçelerinin belirtilerek yazılacağı hükme bağlanmıştır. Aynı şekilde Kanun'un 61. maddesinde Koruma Yüksek Kurulu ve koruma bölge kurullarının kararlarına kamu kurum ve kuruluşları ve belediyeler ile gerçek ve tüzel kişilerin uymak zorunda olduğu hükmü yer almaktadır. Ancak Kanun, Koruma Yüksek Kurulunun ilke kararlarının Resmî Gazetede yayımlanmasını zorunlu tutmakla birlikte koruma bölge kurulları kararları için böyle bir yayım zorunluluğu öngörmemiştir. Alınan kararların ilgili herkesin bilgisine sunulmaması nedeniyle ulaşılabilirlik ve öngörülebilirlik açısından sorunlar çıkması kaçınılmazdır. Hem tescil kararının tebliğ edilmemesi hem de koruma bölge kurulu kararlarının ilgililere duyurulmasını güvence altına alacak bir yasal hükmün bulunmaması karşısında itiraz konusu kurallarda belirtilen cezai yaptırımların bireyler açısından öngörülebilir olmadı̆̆ ve suçların kanunîliği ilkesine uymadı̆̆g açıktır. Açıklanan nedenlerle kural, Anayasa'nın 2. ve 38. maddelerine aykırıdır. Iptali gerekir."

Karar iptale konu edilen husus bakımından isabetlidir. Ancak özellikle bu çalışmanın da konusunu teşkil eden hususların ne iptal talebine ne de iptalin esasına konu olmaması önemli bir eksikliktir. 2863 sayılı Kültür ve Tabiat Varlıklarını Koruma Kanunu'nun 65. maddesinin, normun koruma amacı da göz önünde bulundurularak Kanun'un 9. maddesi ile birlikte mutlaka kanunîlik ve belirlilik açısından anayasaya uygunluk bakımından değerlendirilmesi gerekirdi.

\section{SÜRDÜRÜLEBILIIR KORUMA VE KONTROLLÜ KULLANIM ALANI İLE İLGILI TARTIŞMALI HUSUSLAR}

\section{A. Sürdürülebilir Koruma ve Kontrollü Kullanım Alanı Tanımlarının İdarî Düzenlemelere Bırakılması}

Anıldığ1 üzere tescili söz konusu olabilecek bu yerlerin tanımları KültürTK m.1 I a'da yapılmış, ancak burada sürdürülebilir koruma ve kontrollü kullanım alanı ${ }^{54}$ tanımına yer verilmemiştir. KültürTK m.1 kapsamındaki tanımlara göre: ${ }^{55}$

“(1) "Kültür varlıkları"; tarih öncesi ve tarihi devirlere ait bilim, kültür, din ve güzel sanatlarla ilgili bulunan veya tarih öncesi ya da tarihi devirlerde sosyal yaşama konu olmuş bilimsel ve kültürel açıdan özgün değer taşıyan yer üstünde, yer altında veya su altındaki bütün taşınır ve taşınmaz varlıklardır.

(2) "Tabiat varlıkları"; jeolojik devirlerle, tarih öncesi ve tarihi devirlere ait olup ender bulunmaları veya özellikleri ve güzellikleri bakımından korunması gerekli, yer üstünde, yer altında veya su altında bulunan değerlerdir.

(3) "Sit”; tarih öncesinden günümüze kadar gelen çeşitli medeniyetlerin ürünü olup, yaşadıkları devirlerin sosyal, ekonomik, mimari ve benzeri özelliklerini yansıtan kent ve kent kalıntıları, kültür varlıklarının yoğun olarak bulunduğu sosyal yaşama konu olmuş veya önemli tarihi hadiselerin cereyan ettiği yerler ve tespiti yapılmış tabiat özellikleri ile korunması gerekli alanlardir.

\footnotetext{
${ }^{54} \mathrm{Bu}$ alanlar hakkında bkz. SANCAKTAR, Oğuz/YAĞCI, Pınar/TAŞYILDIZ, Şükür/ÇIRAK: Ezgi, Kültür ve Tabiat Varlıkları Hukuku, 1. Bask1, Adalet Yayınevi, Ankara 2021, s.296.

${ }^{55} \mathrm{Bu}$ kavramlar hakkında ayrıntılı açıklamalar için bkz. SANCAKTAR/YAĞCI/TAŞYILDIZ/ÇIRAK, s.41 vd.; YAĞCI, Ali/TAŞ, Rabia/KILIÇ, Tuğçe: Açıklamalı İçtihatlı, Kültür ve Tabiat Varlıklarını Koruma Kanunu, 1. Baskı, Adalet Yayınevi, Ankara, 2016, s.5 vd.
} 
(4) "Koruma" ve "Korunma"; taşınmaz kültür ve tabiat varlıklarında muhafaza, bakım, onarım, restorasyon, fonksiyon değiştirme işlemleri; taşınır kültür varlıklarında ise muhafaza, bakım, onarım ve restorasyon işleridir.

(5) "Korunma alanı”; taşınmaz kültür ve tabiat varlıklarının muhafazaları veya tarihi çevre içinde korunmalarında etkinlik taşıyan korunması zorunlu olan alandır.

$---$

(13) "Doğal (tabii) sit"; jeolojik devirlere ait olup, ender bulunmaları nedeniyle olağanüstü özelliklere sahip yer üstünde, yer altında veya su altında bulunan korunması gerekli alanlardır".

Bunun yanında Korunan Alanların Tespit, Tescil ve Onayına İlişkin Usul ve Esaslara Dair Yönetmelik m.6/2 eliyle, "doğal sit alanları; kesin korunacak hassas alanlar, nitelikli doğal koruma alanları ve sürdürülebilir koruma ve kontrollü kullanım alanları olarak üç kategoriye” ayrılmıştır. Bunun yanında bu alanların tanımlarına Yönetmelik' te de yer verilmemiş ancak, m.9 içerisinde ayırt edici özellikleri sıralanmıştır:

"Kesin korunacak hassas alanlar veya nitelikli doğal koruma alanlarını etkileyen, bu koruma bölgeleri ile bütünlük gösteren, korumaya katkı sağlayacak, doğal ve kültürel bakımdan uyumlu düşük yoğunlukta faaliyetler, turizm ve yerleşimlere izin veren alanlardır. (2) $\mathrm{Bu}$ alanlar aşağıdaki özelliklerden bir veya birkaçını bünyesinde bulundurur. a) Peyzajı ile uyumlu insan yerleşimlerini içinde bulundurur. b) Doğal kaynak yönetim sistemleri ve ilgili kültürel değerleri, ekosistemleri ve habitatları içerir veya korunmasına katkı sağlar. c) İnsanlar ve doğa arasında dengeli ilişkilerin geliştirilmesine ve muhafaza edilmesine katkıda bulunur. ç) Uygulanabilir durumlarda yerel halkın sosyal ve ekonomik kazançlarına katkı sağlar. d) Ulusal, bölgesel ve yerel seviyelerde doğal kaynakların sürdürülebilir kullanımına ve kalkınmaya destek olur. e) Ekolojik, ekonomik ve sosyal boyutları dikkate alarak doğal kaynakların sürdürülebilir koruma ve kontrollü kullanımına elverişli alanlardır."

$\mathrm{Bu}$ durum karşısında KültürTK'da yer alan doğal sit, jeolojik devirlere ait olup, ender bulunmaları nedeniyle olağanüstü özelliklere sahip yer üstünde, yeraltında veya su altında bulunan korunması gerekli alanları tanımlamasının yukarıda aktarlan özellikleri içerisinde barındıracak sürdürülebilir koruma ve kontrollü kullanım alanlarını hangi unsurlar yoluyla kapsadığı toplumu oluşturacak ortalama insanlar için oldukça muğlaktır. Yukarıdaki kriterler (peyzajı ile uyumlu insan yerleşimlerini içinde bulunduran, doğal kaynak yönetim sistemleri ve ilgili kültürel değerleri, ekosistemleri ve habitatları içerir veya korunmasına katkı sağlayan vs.) neredeyse her doğal alana uygulanabilir niteliktedir. Sıradan bir arazinin sonradan anılan kriterleri içerisinde barındıran yerlerden olduğunu dolayısıyla sürdürülebilir koruma ve kontrollü kullanım alanı olduğunu ya da olabileceğini öngörebilmek kolay değildir. Bu durumda arazisinin sürdürülebilir koruma ve kontrollü kullanım alanı olarak ilan edildiğini Resmi Gazeteleri ya da ilgili internet sayfaları takip etmeyen biri, hareketleri ile kolaylıkla suç teşkil eden bir alana girebilecektir.

Açıklanan bu nedenlerle idarî düzenleyici işlemler kapsamında sürdürülebilir koruma ve kontrollü kullanım alanlarına ilişkin ayırt edici özelliklerle netleştirilmeye çalışılan maddî unsur, şu hâliyle belirli olmaktan, dolayısıyla da öngörülebilir olmaktan uzaktır. Bu alanların tanımlarının mutlaka KültürTK içerisine alınması, Yönetmelik ayırt edici unsurlarının ise daha açık ve belirli olacak şekilde düzenlenmesi gerekir.

Sürdürülebilir koruma ve kontrollü kullanım alanlarından ne anlaşıldığının açık ve öngörülebilir, kıyas yasağı ve belirlilik ilkesi ihlaline sebep olmayacak şekilde tespiti, suçun tüm maddî unsurlarının da aynı şekilde hukuka uygun olarak yorumlanmasını sağlayacaktır. Gerçekten de özellikle zarar unsuru, inşaî ve fizikî müdahale ya da bakım onarım vs. unsurları yorumlarken normun koruma amacı dolayısıyla da korunmak istenen sürdürülebilir koruma ve kontrollü kullanım alanından ne anlaşılması gerektiği net bir şekilde ortada olmalıdır.

2863 sayılı Kanun m.65/1 kapsamındaki suçlar, sit alanlarının her ne suretle olursa olsun zarar görmesine kasten sebebiyet vermeyi ve izin alınmaksızın inşaî ve fizikî müdahale yapma veya yaptırmayı cezalandırmaktadır. Burada geçen zarar ile izin alınmaksızın inşaî ve fizikî müdahale yapma veya yaptırma maddî unsurları, bu fikranın koruma amacına uygun olarak ve diğer doğal sit alanları değil, sadece sürdürülebilir koruma ve kontrollü kullanım alanı özellikleri göz önünde bulundurularak tespit edilecektir. Sürdürülebilir koruma ve kontrollü kullanım alanları yapıları gereği, diğer sit alanı derecelendirmelerinde koruma ve kullanım bakımından en esnek yapıda olan alanlardır. Bu nedenle ki bu alanlara ilişkin zarar/fizikî/inşaî muamele değerlendirmelerinde bulunurken, bölgenin hangi doğal sit türlerinden olduğu mutlaka göz önünde bulundurulmalıdır. Herhangi bir fiil arkeolojik sit alanına zarar verebilecekken sürdürülebilir koruma alanı bakımından arzu edilir dahi olabilecektir. 
Tüm bu açıklamalar ışığında, zararın doğal sit alanının fizikî dokusunu bozucu ve özgün yapısını kaybetmesine sebep olacak bir nitelikte olması gerektiği sabittir. Yargitay kararlarında bu hususa özellikle dikkat çekmektedir:

“...suça konu yerin 1. derece arkeolojik sit alanında bulunduğu, su borusunun malzemeden yapıldığı, pınara bağlantısının fizikî olmadığı ve toprak zemin üzerinde en fala $20-25 \mathrm{~cm}$ derinliğine döşendiği, ayrıca yol kenarına çekilen tel örgünün demir dikmelerinin de büyük ölçüde karayolu zeminine oturtulduğu, gerek plastik boru döşemesinin gerekse tel örgü çekimi dolayısıyla sit alanının zemininde ve fizikî dokusunda herhangi bir tahribatın oluşmadığı, herhangi bir kültür varlığı eserinin zarar görmediği..., sanık eyleminin zarara neden olmayan müdahale niteliğinde olduğu anlaşılmakla... buna göre gerekli suç tespitinin yapılması..."

Tüm bu açıklamalarla ortaya çıkmaktadır ki suçun tüm maddî unsurlarının yorumlanması sürdürülebilir koruma ve kontrollü kullanım alanlarına ilişkin idarî düzenlemelerin esas alınması ile mümkün olmaktadır. Söz konusu idarî düzenlemelerin açıklığı, unsurların yorumunu ve kişiler tarafından da öngörülebilirliği etkileyen belirleyici hususlardır. Belirlilik ilkesi ve kıyas yasağ 1 ihlallerinin önüne ancak kavramlara ve suç fiilinin nelerden ibaret olacağına yeteri derecede açıklık getirildiğinde geçilebilir. Bu bağlamda doğal sit türlerinin tanımlarının normun koruma amacını net bir şekilde ortaya koyacak şekilde mutlaka KültürTK içerisine alınması gerekir.

Tüm bunların yanında KültürTK sürdürülebilir koruma ve kontrollü kullanım alanlarına ilişkin idarî düzenlemeler eliyle getirilen yeniliklere uyum sağlayamadığı da sabittir. Gerçekten de 2863 sayılı Kanun m.9 gereği esaslı onarım, inşaat, tesisat, sondaj, kısmen veya tamamen yıkma yakma, kazı veya benzeri işler inşaî ve fizikî müdahale sayılır. ${ }^{57} \mathrm{Bu}$ bağlamda basit onarım (sıva tamiri, çatı aktarımı $)^{58} \mathrm{~m} .65$ birinci fikra kapsamında kabul edilmemektedir. Kişinin sürdürülebilir koruma ve kontrollü kullanım alanlarına hiçbir yapı yapmadan, sadece ekim dikim ile uğraşmasının anılan esaslı fizikî müdahaleler kapsamında değerlendirilmemesi gerekir. Zira maddede anılan faaliyetler doğayı tahrip edici ve yıkıcı mahiyettedir. Oysaki iyi tarım uygulamaları ile bitki ekmek doğaya faydalı olacaktır. Bunun "doğanın onarılması" olarak mı anlaşılması, kavramlara yüklenen anlamın kıyas yasağına varacak şekilde geniş yorumlanması anlamına gelecektir. Aynı şekilde KültürTK m.65/4'e göre... tadilat ve tamiratları... izin almaksızın ya da izne aykırı olarak yapma/yaptırma suçu bakımından kişinin yapı yapmaksızın ilgili alanda gerçekleştirdiği, ortamın ekosistemine katkı sunduğu ve doğal sit alanının kendine özgü yapısını bozmayıp bilakis yeniden kazanmasını sağladığı bitki bakımı vs. gibi faaliyetlerin "tadilat ve tamirat olarak" kabul edilmesi, geniş yorumlamada bulunarak kıyas yasağına uymama anlamına gelecektir. Geniş yorumlamak, sırf başka bir hüküm/olaya yakın olduğu düşünülerek hükmü amacı dışında, benzeriyle örtüşecek şekilde yorumlamaktır.

\section{B. Sürdürülebilir Koruma ve Kontrollü Kullanım Alanında İzne Tabi Faaliyetler}

İzin almaksızın inşaî ve fizikî müdahale suçu bakımından hangi faaliyetin izne tabi olduğu hangisinin olmadığı KültürTK içerisinde açıkça öngörülmemiş, bu husus tam tersine Yönetmelik ya da ilke kararlarına bırakılmıştır. Sürdürülebilir koruma ve kontrollü kullanım alanlarında izne tabiilik hakkında esas alınacak idarî düzenlemelerin başında 2012 tarihli "Korunan Alanların Tespit, Tescil ve Onayına İlişkin Usul ve Esaslara Dair Yönetmelik" ile ilke kararları gelmektedir. Yönetmelik m.9 şöyledir: "Sürdürülebilir koruma ve kontrollü kullanım alanlarının ayırt edici özellikleri”:

"Kesin korunacak hassas alanlar veya nitelikli doğal koruma alanlarını etkileyen, bu koruma bölgeleri ile bütünlük gösteren, korumaya katkı sağlayacak, doğal ve kültürel bakımdan uyumlu düşük yoğunlukta faaliyetler, turizm ve yerleşimlere izin veren alanlardır. (2) Bu alanlar aşağıdaki özelliklerden bir veya birkaçını bünyesinde bulundurur. a) Peyzajı ile uyumlu insan yerleşimlerini içinde bulundurur. b) Doğal kaynak yönetim sistemleri ve ilgili kültürel değerleri, ekosistemleri ve habitatları içerir veya korunmasına katkı sağlar. c) İnsanlar ve doğa arasında dengeli ilişkilerin geliştirilmesine ve muhafaza edilmesine katkıda bulunur. ç) Uygulanabilir durumlarda yerel halkın sosyal ve ekonomik kazançlarına katkı sağlar. d) Ulusal, bölgesel ve yerel seviyelerde doğal kaynakların sürdürülebilir kullanımına ve kalkınmaya destek olur. e) Ekolojik, ekonomik ve sosyal boyutları dikkate alarak doğal kaynakların sürdürülebilir koruma ve kontrollü kullanımına elverişli alanlardır."

\footnotetext{
56 12. CD, 16.09.2020- 4378/4721; benzer şekilde 12. CD 23.06.2020-4159/3845; 12. CD. 23.06.2020, 13460/38931

57 Ayrıntılı bkz. SANCAKTAR/YAĞCI/TAŞYILDIZ/ÇIRAK, s.919 vd.; YAĞCI/TAŞ/KILIÇ, s.302 vd.; GÜNAY, Erhan: Kültür ve Tabiat Varlıklarını Koruma Yasasındaki Suçlar, 2. Baskı, Seçkin Yayıncılık, Ankara 2021, s.19 vd., $31 \mathrm{vd}$.

58 YAĞCI/TAŞ/KILIÇ, s.55.
}

Gülsün AYHAN AYGÖRMEZ 
hükümden çıkarılacağı üzere Yönetmelik’te izne dair bir hüküm bulunmamaktadır. 25 Ocak 2017 tarihinde 29959 sayılı Resmi Gazete'de yayımlanan, Çevre ve Şehircilik Bakanlığının 99 sayılı "Doğal Sit Alanları Koruma ve Kullanma Koşulları İlke Kararında ise şu hususlar yer almaktadır:

"C- Sürdürülebilir Koruma ve Kontrollü Kullanım Alanları" bakımından "Kesin korunacak hassas alanlar veya nitelikli doğal koruma alanların etkileyen, bu koruma bölgeleri ile bütünlük gösteren, korumaya katkı sağlayacak, doğal ve kültürel bakımdan uyumlu düşük yoğunlukta faaliyetler, turizm ve yerleşimlere izin veren alanlardır. 1. Toprak, cüruf, çöp, hafriyat, sanayi artı̆̆ gibi maddelerin dökülmeyeceğine, 2. Ancak bu alanlarda Tabiat Varlıklarını Koruma Bölge Komisyonu izniyle; a. Kesin Korunacak Hassas Alanlar ile Nitelikli Doğal Koruma Alanlarındaki faaliyetlerin yapılabileceğine, b. Örtü altı tarım, kültür balıkçılığı ve entegre tarım ve hayvancılık faaliyetlerinin yapılabileceğine, c. Katı atık düzenli depolama tesisi, atık su arıtma tesisi, yat çekek yeri, akaryakıt istasyonu gibi uygulamaların yapılabileceğine, ç. Üst ölçekli planlara uygun olmak şartıyla sanayi tesislerinin yapılabileceğine, d. Doğal peyzaj ve siluet dikkate alınarak kum, çakıl, taş, maden ve benzeri malzeme alınabileceğine, bu amaçla ocak açılabileceğine"

Bu ilke kararı 2019 yılında yürürlükten kaldırılarak, 7 Aralık 2019 tarihli 30971 sayılı Resmi Gazete'de 109 sayılı "Doğal Sit Alanları Koruma ve Kullanma Koşulları İlke Kararı" yürürlüğe girmiştir. Buna göre:

"C- Sürdürülebilir Koruma ve Kontrollü Kullanım Alanı: Barındırdığı siluet, jeolojik ve ekolojik değerlerin korunması ve geliştirilmesi amacıyla alanın potansiyeli ve kullanım özellikleri göz önünde bulundurularak, doğal ve kültürel bakımdan uyumlu düşük yoğunlukta faaliyetler, turizm ve yerleşimlere izin veren alanlardır. Bu alanlar; ulusal, bölgesel ve yerel seviyelerde doğal kaynakların sürdürülebilir kullanımına ve kalkınmaya destek olan, insanlar ve doğa arasında dengeli ilişkilerin geliştirilmesine ve muhafaza edilmesine katkıda bulunan, ekonomik ve sosyal boyutları dikkate alarak doğal kaynakların sürdürülebilir koruma ve kontrollü kullanımına elverişli yerlerdir. Bu alanlar; Kesin korunacak hassas alanlar veya nitelikli doğal koruma alanlarını etkileyen, bu koruma bölgeleri ile bütünlük gösteren tampon bölgeler olup düşük yoğunluklu yerleşim yerleri olarak planlanabilir. Sit kararı öncesi alınan ruhsatlı yapılar mevcudiyetini korur. Kentsel yerleşik alanlarda ve kentsel dönüşüm alanlarında yoğunluk, yapılacak koruma amaçlı imar planlarında belirlenebilir. Bu alanlarda sanayi tesislerine izin verilmez, ancak mevcut ruhsatlı sanayi tesisleri, gerekli çevresel tedbiri almak koşulu ile kullanılabilir."

$\mathrm{Bu}$ alanlarda; koşulları, kapsamı, süresi Tabiat Varlıklarını Koruma Bölge Komisyonları tarafından belirlenmek şartı ile aşağıdaki faaliyetlere izin verilebilir. “... ç. Koruma amaçı imar planı veya geçiş dönemi koruma esasları ve kullanma şartlarına uygun olmak ve diğer kurum görüşlerindeki sınırlamalar saklı kalmak kaydıyla tarım ve hayvancılık faaliyetlerine izin verilebilir."

Yine 31070 sayılı 16 Mart 2020 tarihli Resmi Gazete'de yayımlandı̆̆ı üzere, Korunan Alanların Tespit, Tescil ve Onayına İlişkin Usul ve Esaslara Dair Yönetmelik’te, sürdürülebilir koruma ve kontrollü kullanım alanlarının ayırt edici özellikleri hükümlerinin yer aldığı madde 9 kapsamında bazı değişikliklere gidilmiş ve söz konusu olay bakımından önem arz eden 3. fikra norma eklenmiştir: Buna göre:

"Sürdürülebilir koruma ve kontrollü kullanım alanları; barındırdığı siluet, jeolojik ve ekolojik değerlerin korunması ve geliştirilmesi amacıyla alanın potansiyeli ve kullanım özellikleri göz önünde bulundurularak, kesin korunacak hassas alan ve nitelikli doğal koruma alanlarında izin verilen faaliyetlere ek olarak doğal ve kültürel bakımdan uyumlu düşük yoğunlukta faaliyetler, entegre tesis, turizm ve yerleşimlere izin veren alanlardır... (3) Sürdürülebilir koruma ve kontrollü kullanım alanlarında bulunan madenlerin milli menfaatlere uygun olarak aranması, hangi şartlarda ve ölçülerde işletileceği, kapatılması ve alanın rehabilitasyonu ilke kararları doğrultusunda alınacak olan Bölge Komisyonlarının kararları doğrultusunda yapılır.”

Tüm bu idarî işlemler göz önünde bulundurulduğunda, sürdürülebilir koruma ve kontrollü kullanım alanında hangi faaliyetler için izin alınması gerektiği, nelerin izne tabii olmadığ 1 hem belirsizleşmiş hem zaman içinde ciddi değişikliklere uğramıştır. Örneğin 99 sayılı İlke Kararı örtülü ve entegre tarım için izin şartı getirirken, bunun dışındaki tarımsal faaliyetler izin aramamıştır. Ancak bunun ardından çıkarılan 109 numaralı ilke kararı her türlü tarımcılığı izne bağlamıştır. En nihayetinde 2020 yılındaki Yönetmelik madencilik işleri ile alakalı karardan bahsetmiş, bunun dışındaki faaliyetlere ilişkin ciddi bir soru işareti doğmasına sebep olmuştur.

Tüm bu hususlar hem kanunsuz suç ve ceza olmaz ilkesi hem de belirlilik ve suç ve cezaların geriye yürümezliği ilkesi açısından ciddi anlamda sorunlar doğurmaktadır. İzin, gerek KültürTK m.65 1. fikra gerekse 4. fikra kapsamında suç isnadı ve yaptırımının esasını oluşturan kurucu bir 
unsurdur, hangi faaliyetlerin izne tabii olduğu hususu, suçun kurucu unsuru olduğundan sadece kanun eliyle düzenlenebilecek iken, bunun Yönetmelik, hatta sürekli değişen ilke kararlarına bırakılması, kanunsuz suç ve ceza olmaz ilkesini ihlal etmektedir. Bunun yanında yapılan tanımlama eksiklikleri ve sürekli değişiklikler öngörülebilirliğe helal getirdiğinden belirlilik ilkesini ihlal etmektedir. Yine yapılan sürekli değişim fiilin suç olup olmamasına da esaslı etkide bulunduğundan suç ve cezada geriye yürüme ve fail lehine hüküm uygulama gibi birçok sorunu beraberinde getirmekte ve anılan ilkeleri de ihlal etmektedir.

Yukarıda ayrıntılarıyla aktarıldığı üzere Anayasa Mahkemesi, suç unsurlarının yasa içerisinde açıkça belirtilmiş olmasını kanunîlik ilkesi bakımından zorunlu görmektedir. Kesinlik taşıyan, kişisel bakış açısına göre değişmeyen, anlamları uygulamalarla belirmiş, hukuk ve Anayasa terminolojisi hâline gelmiş dolayısıyla hukuk dilinde oturmuş terimler belirlidir. Suç unsurlarının oluşumunda esas teşkil edecek kurucu unsurların zamanla sürekli değişen, karmaşık, çelişkili idarî düzenlemelere bırakılması yasallık ilkesinin çiğnenmesi anlamına gelmektedir.

\section{SONUÇ}

Aktarılan tüm sorunlu ve belirsiz unsurlar, uygulayıcı ve teorisyenleri dahi ikilemlere düşürebilecekken, toplumu oluşturan ortalama insan kesiminin bunlara uyum sağlamasını neredeyse imkânsızlaştırmaktadır. Hukukî güvenliğin egemen olduğu hukuk devletinde, hangi hareketin suç teşkil edeceği yasalarda açıkça ve toplumun ortalama kesimi anlayacak şekilde düzenlenmelidir. Vatandaşın hareketlerinin sonuçlarını öngörebilmesi, böylelikle de haklı yerine haksız olanı seçmesinin önüne geçilmesi sağlanmalıdır. Bunun için de kişileri hareketinin suç teşkil edip etmediğini öngöremeyecek şekilde hızlı değişen, karmaşık yapılı Yönetmelik ve ilke kararlarından kaçınılarak, yasallık ilkesi gereklerine uygun yasa normları yaratılmalıdır. Kişilerin düzenleyici idarî işlemleri anlamama, yorumlayamama ve tam olarak bilmemesi karmaşıklaşan toplumsal bir yapıda ve sağlıklı bilgi kaynaklarına erişmenin tüm internet imkânlarına rağmen zayıfladığı bir ortamda kaçınılmaz olmaktadır. Kanun koyucunun özellikle herkes tarafından bilinmeyecek, genel geçer olamayacak özel kanunlardaki suçlar bakımından daha özenli olması, bu kanunlardaki suçları kanun içerisinde daha öngörülebilir bir açıklıkla norma bağlaması gerekir. Normların belirsizliği, kişilere yüklenecek bir kusur olmamalıdır.

Ceza hukuku karineler hukuku değildir. Ceza hukukunda suç isnadı, kişilerin doğal sit kararına ilişkin tapuya tescil ile internet sayfası gibi alanlarda yapılan duyuruları bilmesi ve fark etmesi üzerine oturamaz. Kişilerin aynı zamanda doğal sit alanında kalanında arsasında hangi fiillerinin suç teşkil edebileceğini açıkça öngörebilmeleri de gerekir. Bu öngörü ise ancak kanun esaslı ve açık yasal düzenlemeler sonrası kişilerden beklenebilir. Bilmemek kastın kurucu unsuru olduğundan, kişilerin kastı ortadan kalkacak şekilde hatalara düşmesinin önüne ancak kanun koyucu tarafından kanunîlik ilkesine uyulması ile geçilebilir. 


\section{KAYNAKÇA}

ARTUK, Mehmet Emin/GÖKCEN, Ahmet/ALŞAHİ, Mehmet Emin/ÇAKIR, Kerim: Ceza Hukuku Genel Hükümler, 14. Bask1, Adalet Yayınevi, Ankara, 2020.

AYGÖRMEZ, Gülsün Ayhan: Çevre Ceza Hukuku, Çevre Ceza Genel Hükümler, Cilt 1, 1. Baskı, On İki Levha Yayınc1lık, İstanbul, 2021.

AYGÜN EŞİTLİ, Ezgi: Suçların ve Cezaların Kanunîliği İlkesi, TBBD, (104), 2013, s.225-246.

BAYTAZ, Abdullah Batuhan: Kanunîlik İlkesi Bağlamında Ceza ve Ceza Muhakemesi Hukukunda Yorum, Onikilevha Yayıncılık, İstanbul, 2018.

BOSTANCI Gülşah: Avrupa İnsan Hakları Sözleşmesi Bağlamında Türk Ceza Hukukunda Suçta ve Cezada Kanunîlik İlkesi, Yayınlanmamış Yüksek Lisans Tezi, İstanbul Üniversitesi Sosyal Bilimler Enstitüsü, 2007.

CAN, Osman: Belirlilik İlkesine Anayasal Bakış, AÜEHFD, IX(1-2), 2005, s.89-125.

CENTEL, Nur/ZAFER, Hamide/YENERER ÇAKMUT, Özlem: Türk Ceza Hukukuna Giriş, 11. Baskı, Beta, İstanbul, 2020.

DEMİRBAŞ, Timur: Ceza Hukuku Genel Hükümler, 16. Baskı, Seçkin Yayınevi, Ankara, 2021.

GÖKCAN, Hasan Tahsin/ARTUÇ, Mustafa: Yorumlu - Uygulamalı Türk Ceza Kanunu Şerhi, 1. Cilt, m.144, Adalet Yayınevi, Ankara 2021.

GÜNAY, Erhan: Kültür ve Tabiat Varlıklarını Koruma Yasasındaki Suçlar, Seçkin Yayıncılık, 2. Baskı, Ankara, 2021.

HAKERİ, Hakan: Ceza Hukuku, Genel Hükümler, 18. Bask1, Adalet Yayınevi, Ankara, 2015.

KANGAL, Zeynel: “Anayasal Güvence Olarak Suçta ve Cezada Kanunîlik İlkesi”, Ceza Hukuku Dergisi, (17), 2011, s.61-106.

KOCA, Mahmut/ÜZÜLMEZ, İlhan: Türk Ceza Hukuku Genel Hükümler, 12. Baskı, Seçkin Yayıncılık, Ankara, 2019.

KORKMAZ, Mehmet: Kanunîlik İlkesinin Bir Sonucu Olarak Ceza Kanunlarının Belirlilik İlkesi, Prof. Dr. Mehmet Emin Artuk’a Armağan, Seçkin Yayıncılık, Ankara, 2020.

MAHMUTOĞLU, Fatih Selami/KARADENIZ, Serra: Türk Ceza Kanunu Genel Hükümler Şerhi, 2. bask1, Beta yayınevi, İstanbul, 2021.

ÖZGENÇ, İzzet: Türk Ceza Hukuku Genel Hükümler, 17. Baskı, Seçkin Yayınevi, Ankara, 2021.

ÖZTÜRK, Bahri/ERDEM, Mustafa Ruhan: Ceza Hukuku ve Güvenlik Tedbirleri Hukuku, 21. Bask1, Seçkin Yayınevi, Ankara, 2021.

SANCAKTAR, Oğuz/YAĞCI, Pınar/TAŞYILDIZ, Şükür/ÇIRAK, Ezgi: Kültür ve Tabiat Varlıkları Hukuku, 1. Bask1, Adalet Yayınevi, Ankara, 2021.

SOYASLAN, Doğan: Ceza Hukuku, Genel Hükümler, Yetkin Yayınları, Ankara, 1998.

YAĞCI, Ali/TAŞ, Rabia/KILIÇ, Tuğçe: Açıklamalı İçtihatlı, Kültür ve Tabiat Varlıklarını Koruma Kanunu, 1. Bask1, Adalet Yayınevi, Ankara, 2016.

YARSUVAT, Duygun: Yürütme Organının Koyduğu Kaidelerle Suç İhdası ve 1961 Anayasası, Journal of Istanbul University Law Faculty 29(3), 2011, s.540-559.

ZAFER, Hamide: Ceza Hukuku Genel Hükümler Ders Kitab1, 7. Bask1, Beta Yayınları, Ankara, 2021. 